\title{
Tytuł profesora w Polsce w latach 1920-1990. Część 1. Warunki przyznawania tytułu profesora w prawie szkół wyższych
}

\section{Wprowadzenie}

Polskim uczonym tytuł profesora nadawano zarówno po uzyskaniu przez Rzeczpospolitą Polską w 1918 r. niepodległości, jak i w latach późniejszych przemian. Współczesne rozwiązania w tym zakresie obowiązujące od tego standardu nie odbiegają w tym sensie, że nadanie tytułu profesora zwyczajnego wiążą z ukoronowaniem dotychczasowej pracy badawczej uczonego. I tak być powinno. Na przestrzeni lat prawodawca przyjmował tu jednak różne rozwiązania. Trudność w ich ocenie tkwi nie tyle $\mathrm{w}$ tym, jakie tytuły profesorskie proponowano i jakie przesłanki definiowały prawo prowadzące do ich nabycia (jeśli je prawem ujmowano), lecz w tym, co przemawiało za zasadnością różnicowania tytułów profesora i ich kwalifikowania jako tytułu naukowego bądź tytułu wymagania tego niespełniającego. To, że począwszy od 1918 r., zmieniały się warunki ustrojowe państwa i jego potrzeby, nie dziwi, takie sa pozytywne i negatywne strony każdego od nowa odtwarzanego państwa i kształtowania warunków jego dalszego rozwoju. Akcentowanie polskości bardziej lub mniej ideologicznie w minionych latach zapewne skłania do szczególnej refleksji nie tylko historyka. Tu natomiast ważniejsza jest odpowiedź na pytanie, czy i w jakim stopniu na przestrzeni analizowanych lat polityczne uwarunkowania, lub też inne względy, dyktowały prawne warunki nabycia tytułu profesorskiego, w szczególności które z nich były tytułem naukowym, a także jaki był tryb postępowania prowadzący do jego nadania. 
Nie mniej ważna jest odpowiedź na pytanie, czy ówczesne prawo chroniło wolność naukową kandydata na drodze prowadzącej do tytułu profesora, czy było jedynie jego fasada. Jest to zagadnienie nie bez znaczenia, jeśli się zważy, że objęte siedemdziesięcioletnim okresem przyznawanie tego tytułu odnieść należy do Polski w różnych jej warunkach polityczno-ustrojowych (II Rzeczpospolita, pierwsze lata Polski Ludowej, Polska Rzeczpospolita Ludowa).

Do roku 1965 prawo przyznawania tytułów profesora regulowały przepisy dotyczące ówczesnych szkół wyższych. Od marca tegoż roku ustawodawca przyjął inne rozwiązanie. Wyłączył prawo nadawania stopni naukowych i tytułów naukowych z prawa szkolnictwa wyższego. W ten sposób rozdzielił prawną regulację kształcenia w szkołach wyższych od prawa kształcących do awansów naukowych, co skłania do zbadania i ujęcia tej problematyki w dwóch częściach: (1) obejmującej lata uregulowanej prawem szkolnictwa wyższego oraz (2) objętej odrębną regulacją. Omówienie tego zagadnienia w osobnych opracowaniach jest zasadne także ze względu na potrzebę zbadania, na ile rozdzielenie prawnej regulacji $\mathrm{w}$ zakresie profesur $\mathrm{w}$ dwóch aktach ustawowych o różnych ich tytułach było uwarunkowane aktualną potrzebą i na ile zabieg ten był uzasadniony.

\section{Tytuły profesora w Polsce - wprowadzenie do rozważań}

We wszystkich okresach objętych analizą nadanie tytułu profesorskiego wiązano z zatrudnieniem $\mathrm{w}$ szkole wyższej osoby do niego pretendującej. Ponadto nadanie tego tytułu $z$ reguły leżało w gestii najwyższej władzy państwowej. O ile paradygmat pierwszy na przestrzeni lat wiele się nie zmieniał, o tyle zmieniała się władza państwowa nadająca tytuły profesora oraz wskazująca warunki i tryb postępowania prowadzące do ich nadania. Zmieniał się też udział podmiotów w postępowaniach tych współuczestniczących.

W początkowym okresie po uzyskaniu w 1918 r. niepodległości Polska nie dysponowała liczną kadrą kształcąca, jeszcze mniej było osób posiadających tytuł profesora ${ }^{1}$ zatrudnionych w ówczesnych szkołach

${ }^{1}$ Dlatego nie bez znaczenia pozostawało tu postanowienie art. 47 ust. 2 Ustawy z dnia 13 VII 1920 r. o szkołach akademickich (Dz.U. RP Nr 72, poz. 494 ze zm.), zgodnie z którym „[p]rofesorowie, którzy byli już zwyczajnymi lub nadzwyczajnymi profesorami w polskich albo innych równorzędnych szkołach akademickich przed rokiem 1915, mają 
akademickich². I choć sytuacja ta ulegała stopniowej poprawie w latach następnych Polski międzywojnia ${ }^{3}$, przyznawania tytułów, pod rządami obu ówcześnie obowiązujących ustaw o szkołach akademickich (1920,

prawo pozostawać profesorami zwyczajnymi lub nadzwyczajnymi i po upływie 35 lat pracy profesorskiej bez ponownego powoływania [...]".

${ }^{2}$ Ustawa z 1920 r. o szkołach akademickich - w brzmieniu pierwotnym, wymienia dziesięć państwowych szkół akademickich: Uniwersytet Jagielloński w Krakowie (szerzej: K. Stopka, J. Banach, J. Dybiec, Dzieje Uniwersytetu Jagiellońskiego, Kraków 2000); Uniwersytet Stefana Batorego w Wilnie, Uniwersytet Jana Kazimierza we Lwowie (szerzej: J. Draus, Uniwersytet Jana Kazimierza we Lwowie 1918-1946. Portret uczelni kresowej, Kraków 2007); Uniwersytet Warszawski (szerzej: J. Miziołek, Uniwersytet Warszawski: dzieje i tradycja, Warszawa 2005); Uniwersytet Poznański (szerzej: K. Krasowski, Zarys dziejów Wydziatu Prawa Uniwersytetu w Poznaniu 1919-2004, Poznań 2004); Szkołę Politechniczną we Lwowie, Politechnikę Warszawska, Akademię Weterynarii we Lwowie, Szkołę Główną Gospodarstwa Wiejskiego w Warszawie, Akademię Górniczą w Krakowie). W 1924 r. na mocy Ustawy z dnia 16 VII 1924 r. o zmianie niektórych przepisów Ustawy z dnia 13 VII 1920 r. o szkołach akademickich rozszerzono to zestawienie o kolejną państwową szkołę akademicką - Akademię Szkół Pięknych w Krakowie. Ustawa ta weszła w życie z dniem 14 I 1925 r. (Dz.U. 1925 Nr 2, poz. 10). Następnie do grupy państwowych szkół akademickich dołączono Akademię Sztuk Pięknych w Warszawie (utworzoną na mocy Ustawy z dnia 18 III 1932 r. o Akademii Sztuk Pięknych w Warszawie, Dz.U. 1932 Nr 30, poz. 305). Do czasu wejścia w życie kolejnej ustawy (z 1933 r.) łącznie dwanaście szkół akademickich mogło zatem współuczestniczyć w procesie nominacji do tytułu profesora i mianowania na stanowisko profesora danego przedmiotu.

${ }^{3}$ Ustawa z dnia 15 III 1933 r. o szkołach akademickich (brzmienie pierwotne Dz.U. Nr 29, poz. 250 ze zm.), przy objęciu nią także Akademii Sztuk Pięknych w Krakowie oraz nadaniu Akademii Sztuk Pięknych w Warszawie z dniem 1 III 1934 r. pełni praw akademickich Rozporządzeniem Rady Ministrów z dnia 21 II 1934 r. o organizacji Akademii Sztuk Pięknych w Warszawie (Dz.U. Nr 16, poz. 126) rozszerzyła przyjętą ustawą z 1920 r. liczbę państwowych szkół akademickich do trzynastu przez dodanie Akademii Stomatologicznej w Warszawie, zarazem przyjmując nowe nazwy dla dwóch dotychczasowych państwowych szkół akademickich: Politechniki Lwowskiej (szerzej: Z. Popławski, Politechnika Lwowska w latach 1844-1945. Rodowody katedr, wykaz nauczycieli akademickich, dziedzictwo, Kraków 1999) i Akademii Medycyny Weterynaryjnej we Lwowie (szerzej: L. Lewandowski, Akademia Medycyny Weterynaryjnej we Lwowie, "Semper Fidelis" 1994, nr 3(20), s. 9-15). Ponadto dodała trzy prywatne szkoły akademickie: Szkołę Główną Handlową w Warszawie, Katolicki Uniwersytet Lubelski - z pełnymi prawami państwowej szkoły akademickiej, szkoła pierwsza od dnia wejścia w życie ustawy z 1933 r. o szkołach akademickich; szkoła druga od 1938 r. (Dz.Urz. MWRiOP 1938 r. Nr 27, poz. 242), oraz Wolną Wszechnicę Polską w Warszawie - z niepełnymi prawami akademickimi od 1931 r.). Ustawą z dnia 29 III 1937 r. o zmianie ustawy z dnia 15 III 1933 r. o szkołach akademickich (Dz.U. RP Nr 27, poz. 192) listę prywatnych szkół akademickich poszerzono, przy zmianie dotychczasowych nazw, o: Akademię Handlu Zagranicznego we Lwowie, trzy akademie (Akademia Handlowa w Krakowie, Akademia Handlowa w Poznaniu oraz Akademia Nauk Politycznych w Warszawie). Łącznie z końcem lat trzydziestych funkcjonowało dwadzieścia uczelni, w tym siedem prywatnych szkół akademickich - z pełnymi prawami akademickimi. Zob. też bp S. Wielgus, Uczelnie 
$\left.1933^{4}\right)$, nie ograniczono jedynie do tytułów profesora nadzwyczajnego i profesora zwyczajnego. Wprawdzie szczególną pozycję pozostawiono także profesorom honorowym ${ }^{5}$, przyznawanie innych tytułów profesora, np. tytularnego, nie było odosobnione. Stopniowe pozyskiwanie nowej kadry profesorskiej nie zaspokajało jednak wszystkich potrzeb dydaktycznych szkół akademickich. Ten brak rekompensowano wprowadzeniem m.in. tytułu profesora kontraktowego czy zastępcy profesora. I choć ich nadawanie leżało wyłącznie w gestii naczelnej władzy państwowej, nie były to tytuły naukowe, tak jak tytułami naukowymi nie były prawem przewidziane tytuły nadawane pomocniczym pracownikom nauki (np. adiunktom, asystentom, lektorom).

Wprawdzie z końcem 1938 r. liczba szkół akademickich ${ }^{6}$, a zatem i profesorów zwyczajnych i nadzwyczajnych wzrosła ${ }^{7}$, jednak II wojna światowa nie tylko tę tendencję rosnącą zahamowała, lecz co gorsza, przeprowadzanymi przez najeźdźców zamachami na polską inteligencję i wykonanymi egzekucjami poważnie także uszczupliła grono profesorów polskich szkół akademickich. W efekcie po zakończeniu II wojny światowej polskie uczelnie ponownie znalazły się w trudnym położeniu. Tę trudność pogłębiało: ustalenie nowych granic w powojennej rzeczywistości, co skutkowało utratą polskich uczelni położonych na dawnych ziemiach wschodnich przynależnych do Rzeczypospolitej",

wyższe i instytuty naukowe w II Rzeczypospolitej. Polskie Towarzystwa Naukowe, „Notatki Płockie" 2002, nr 3/192, s. 7-8.

${ }^{4}$ Przywołanie w nawiasie roku: 1920, 1933 bez bliższego określenia oznacza odpowiednią ustawę o szkołach akademickich.

${ }^{5}$ Zgodnie z art. 11 ustawy z 13 VII 1920 r. profesor honorowy współtworzył wraz z profesorami zwyczajnymi i nadzwyczajnymi oraz docentami grupę nauczycieli akademickich różną od innych nauczycieli (pomocniczych).

${ }^{6}$ Według Atlasu szkolnictwa wyższego (Warszawa 1937) we lwowskich uczelniach w roku akademickim 1934/1935 pracowało 169 profesorów, 176 samodzielnych pracowników nauki i 478 pomocniczych.

${ }^{7}$ W 1939 r. liczba pracowników nauki w polskich szkołach wyższych wynosiła ponad 1300 osób (profesorowie - ponad 700, docenci - około 600), a pomocniczych pracowników nauki - 2100 osób. W roku akademickim 1938/1939 szkołom akademickim przyznano 824 etaty profesorskie, z których 107 nie obsadzono. Podaję za: bp S. Wielgus, op. cit., s. 9.

${ }^{8} \mathrm{~W}$ wyniku ustalenia nowych granic wschodnich i północnych ze Związkiem Radzieckim, ostatecznie zatwierdzonych umową zawartą między Tymczasowym Rządem Jedności Narodowej a rządem Związku Socjalistycznych Republik Radzieckich dnia 16 VIII 1945 r., wchodzącą w życie w dacie wymiany dokumentów ratyfikujących 5 II 1946 r. (Dz.U. RP 1947 Nr 35, poz. 167 i 168), poza granicami Polski znalazło się pięć szkół akademickich: Uniwersytet Stefana Batorego w Wilnie, Uniwersytet Jana Kazimierza 
oraz podjęcie działań prowadzących do budowania ustroju politycznego i społecznego kraju w warunkach dla Polski nowych, sowieckich.

Na wzór radziecki ustrój i funkcjonowanie szkół wyższych ukształtowano nie od razu. Dopiero z końcem października 1947 r. na nowo, w drodze dekretu' ${ }^{9}$, określono organizację nauki i szkolnictwa wyższego. Aktem tym zachowano niektóre rozwiązania obowiązujące przed 1939 r., w tym te dotyczące tytułów profesora (honorowego, zwyczajnego i nadzwyczajnego). Tak jak miało to miejsce pod rządami wcześniejszych ustaw, dekret przewidywał także tytuły: profesora tytularnego, profesora kontraktowego i zastępcy profesora.

Rok 1951 przyniósł w tym zakresie zmiany. Ustawa z dnia 15 grudnia $1951 \mathrm{r}^{10}$, choć zachowała tytuły profesora nadzwyczajnego i zwyczajnego, po raz pierwszy określiła je wprost tytułami naukowymi i po raz pierwszy też wprowadziła odpowiednie ich stosowanie do pracowników nauki zatrudnionych $w$ instytutach naukowych dla potrzeb gospodarki narodowej ${ }^{11}$ lub w Polskiej Akademii Nauk ${ }^{12}$ (PAN) i jej placówkach naukowych. Zrezygnowała z instytucji profesora honorowego, zachowała natomiast tytuły (nienaukowe) dla pomocniczych pracowników nauki, sprowadzając je jedynie do: adiunktów, starszych asystentów i asystentów. Ten stan rzeczy nieco zmieniła ustawa kolejna, z 1958 r. ${ }^{13}$ Wprawdzie tytuły naukowe profesora nadzwyczajnego i zwyczajnego pozostały, lecz zarazem zastrzeżono wyraźnie, że tytuły te są nadawane dożywotnio. Wzorem rozwiązań wcześniejszych (sprzed 1951 r.) powrócono do instytucji tytułu profesora kontraktowego oraz zastępcy profesora.

W 1965 r. z prawa szkolnictwa wyższego wyłączono sprawy nadawania tytułów profesora. Odtąd normowała je Ustawa z dnia 31 marca 1965 r. o stopniach naukowych i tytułach naukowych ${ }^{14}$. Ustawą tą za-

we Lwowie, Szkoła Politechniczna we Lwowie, Akademia Handlu Zagranicznego we Lwowie oraz Akademia Weterynarii we Lwowie.

${ }^{9}$ Dekret z dnia 28 X 1947 r. o organizacji nauki i szkolnictwa wyższego (Dz.U. Nr 68, poz. 415).

${ }^{10}$ Ustawa z dnia 15 XII 1951 r. o szkolnictwie wyższym i o pracownikach nauki (Dz.U. $1952 \mathrm{Nr} 6$, poz. 38 ze zm.).

${ }^{11}$ Ustawa z dnia 8 I 1951 r. o tworzeniu instytutów naukowo-badawczych dla potrzeb gospodarki narodowej (Dz.U. Nr 5, poz. 38). Zob. też Ustawa z dnia 17 II $1961 \mathrm{r}$. o instytutach naukowo-badawczych (Dz.U. Nr 12, poz. 160 ze zm.).

${ }^{12}$ Ustawa z dnia 30 X 1951 r. o Polskiej Akademii Nauk (Dz.U. Nr 51, poz. 391), uchylona ustawą kolejną z dnia 17 II 1960 r. o Polskiej Akademii Nauk (Dz.U. Nr 10, poz. 64).

${ }^{13}$ Ustawa z dnia 5 XI 1958 r. o szkołach wyższych (Dz.U. Nr 60, poz. 336).

${ }^{14}$ Ustawa z dnia 31 III 1965 r. o stopniach naukowych i tytułach naukowych (Dz.U. Nr 14, poz. 101). 
chowano dwa tytuły naukowe - profesora nadzwyczajnego i profesora zwyczajnego. Nią też odstąpiono od nadawania innych tytułów, w tym nienaukowych. I ten stan rzeczy utrzymano do września $1990 \mathrm{r}^{15}$

Rozdziałowi materii prawnej w zakresie nadawania tytułów profesora nie towarzyszyło odstąpienie od regulowania prawem szkół wyższych nominacji kadry profesorskiej na określone stanowiska. Zarówno przed rokiem 1965, jak i od tego roku miejsce profesorów w strukturze ówcześnie przyjmowanych stanowisk wyznaczały akty kolejno regulujące ustrój i funkcjonowanie ówczesnych szkół wyższych $(1920,1933$, $\left.1947,1951,1958,1982^{16}\right)$. Nie były to rozwiązania stabilne. Przyjęte nimi unormowania zdecydowanie były wyrazem ówczesnych przemian politycznych sytuujących profesorów w grupie stanowisk bardziej lub mniej wyróżnionych w uczelnianym podziale pracy. W roku 1920 ówczesnych profesorów honorowych, nadzwyczajnych i zwyczajnych (także docentów), stanowiących trzon grona nauczycielskiego, kwalifikowano jako nauczycieli akademickich. Ustawa z 1933 r. rozwiązanie to zachowała, ponadto grupę nauczycieli akademickich poszerzyła o profesorów tytularnych, profesorów kontraktowych i zastępców profesorów (art. 28 ust. 1). Dekretem z $1947 \mathrm{r} .{ }^{17}$ odstąpiono od nazwy "nauczyciele akademiccy", przy zachowaniu terminu "grono nauczycielskie", którym poza kadrą profesorską objęto także nauczycieli przedmiotów pomocniczych (art. 59). W $1951 \mathrm{r}$. od tego rozwiązania odstąpiono. Odtąd, w rozumieniu tej ustawy, profesorom nadzwyczajnym, zwyczajnym (oraz docentom) nadano (po raz pierwszy) status samodzielnych pracowników nauki, w odróżnieniu od pomocniczych pracowników nauki. Tego stanu rzeczy wiele nie zmieniła ustawa z $1958 \mathrm{r}$. w jej pierwotnym brzmieniu. Po jej nowelizacji z $1965 \mathrm{r}^{18}$ kadra profesorska współtworzyła już grupę pracowników naukowo-dydaktycznych, od 1973 r. ${ }^{19}$ - nauczycieli akademickich. W roku $1982^{20}$ termin "nauczyciele akademiccy” zachowano

${ }^{15}$ To jest do czasu wejścia w życie (z dniem 27 IX 1990 r.) Ustawy z dnia 12 IX 1990 r. o tytule naukowym i stopniach naukowych (Dz.U. Nr 65, poz. 386).

${ }^{16}$ Ustawa z dnia 4 V 1982 r. o szkolnictwie wyższym (Dz.U. Nr 14, poz. 113).

17 Artykuł 19 dekretu z 1947 r. do grona nauczycielskiego szkoły wyższej zaliczał profesorów (honorowych, nadzwyczajnych, zwyczajnych, tytularnych, kontraktowych), a także docentów i zastępców profesorów oraz nauczycieli przedmiotów pomocniczych.

${ }^{18}$ Zob. art. 1 pkt 51 Ustawy z dnia 31 III 1965 r. o zmianie ustawy o szkołach wyższych (Dz.U. Nr 14, poz. 98).

${ }^{19}$ Artykuł 74 ust. 1 Ustawy z dnia 5 XI 1958 r. o szkolnictwie wyższym (tekst jedn. Dz.U. 1973 Nr 32, poz. 191).

${ }^{20}$ Zob. art. 130 Ustawy z dnia 4 V 1982 r. o szkolnictwie wyższym. 
(w odróżnieniu od innych pracowników szkoły) i objęto nim: (1) pracowników naukowo-dydaktycznych, (2) pracowników dydaktycznych i (3) pracowników naukowych. Kadra profesorska (profesorowie nadzwyczajni i profesorowie zwyczajni) wraz z innymi stanowiskami (do stanowiska asystenta-stażysty włącznie) tworzyła grupę pracowników naukowo-dydaktycznych (w szkołach wyższych), pracowników naukowych (w placówkach naukowych PAN oraz instytutach naukowo-badawczych, od 1985 roku jednostkach badawczo-rozwojowych ${ }^{21}$ ).

W okresie objętym analiza powierzenie stanowisk profesora nadzwyczajnego i profesora zwyczajnego zwykle było elementem wtórnym, poprzedzonym nadaniem tytułu profesora. Tymczasem droga prowadząca do tego tytułu w każdym $\mathrm{z}$ okresów badanych $\mathrm{w}$ istocie była różna. Abstrahując tu od prawem przewidzianych wyjątków w tym zakresie, sprowadzała się do uprzedniego nabycia wyższego stopnia naukowego: doktora $(1920,1933,1947)$, doktora nauk (1951), docenta (1958), doktora habilitowanego (od 1968), przy różnym określeniu warunków prowadzących do nabycia każdego z tych stopni naukowych $^{22}$. Pod rządami obu ustaw o szkołach akademickich $(1920,1933)$ habilitacja prowadząca do veniam legendi nie była stopniem naukowym; do stopnia naukowego nie prowadziła także przewidziana dekretem (1947) habilitacja zakończona prawem nauczania, aczkolwiek nabyta tą drogą samodzielność wykładania (nauczania) tworzyła warunki do awansu naukowego i zawodowego. Z kolei ustawą z 1951 r. od habilitacji odstąpiono, a powrócono do niej na zmienionych warunkach w 1958 r. Uwzględniając ten aspekt rozwoju naukowego oraz wymagania stawiane przed kandydatami do tytułu profesora, można dostrzec różnice $\mathrm{w}$ oczekiwaniach prawodawcy $\mathrm{z}$ różnych lat kierowanych do kadry profesorskiej, z reguły uzasadnionych wartością zakreślanych ówcześnie ram kwalifikacji naukowych.

Zakres wymaganych kwalifikacji naukowych w prawodawstwie tych lat w niewielkim stopniu ulegał zmianie. Dla uzyskania tytułu profesora

${ }^{21}$ Ustawa z dnia 25 VII 1985 r. o jednostkach badawczo-rozwojowych (Dz.U. Nr 36, poz. 170).

${ }^{22}$ Szerzej zob.: K. Wojtczak, W kwestii wyższego stopnia naukowego doktora w Polsce Ludowej, "Studia Prawa Publicznego" 2016, nr 4(16), s. 33-58, eadem, O stopniach naukowych $i$ veniam legendi $w$ II Rzeczypospolitej (Część II), "Studia Prawa Publicznego" 2014, nr 4(8), s. 22 i n.; eadem, Habilitacje w Polsce Ludowej. Część 1. Warunki i przebieg habilitacji w prawie szkót wyższych, "Studia Prawa Publicznego" 2017, nr 1(17), s. 25-61; eadem, Habilitacje w Polsce Ludowej. Czesść 2. Warunki i przebieg habilitacji w prawie o stopniach i tytułach naukowych, „Studia Prawa Publicznego” 2017, nr 2(18), s. 43-81. 
zwyczajnego wymagano dorobku naukowego: powiększonego (1920), wydatnie powiększonego $(1933,1947)$ lub poważnego $(1951,1958)$, uzyskanego w trakcie profesury nadzwyczajnej. Kwalifikacje naukowe potrzebne do nabycia tytułu profesora nadzwyczajnego formułowały tylko niektóre rozwiązania $\mathrm{z}$ tych lat. $\mathrm{W}$ istocie więc $\mathrm{w}$ latach minionych akcenty wyznaczające wartość naukową kandydata do tytułu profesorskiego rozkładano różnie. Można jedynie zakładać, że miary tej wartości nie wyznaczała wyłącznie liczba opublikowanych prac. Jest to praktyka myląca, a przez to i zawodna. Założyć trzeba, że ocenę powiększonego dorobku naukowego kandydata do tytułu profesora mierzono także jego wartością naukową ${ }^{23}$. Tę zaś w latach minionych kształtowały różne miary, wyznaczone granicami prawnie dopuszczalnej wolności badań naukowych, również $w$ drodze konstytucyjnej ${ }^{24}$.

Począwszy od roku 1920, profesor miał prawo „podawać i oświetlać z katedry w publikacjach naukowych według swego przekonania i sposobem naukowym wszelkie zagadnienia wchodzące $w$ zakres gałęzi wiedzy, których jest przedstawicielem". Podobne rozwiązania przyjęła ustawa z 1933 r. stanowiąca, że „[k]ażdy profesor [...] ma prawo

${ }^{23} \mathrm{O}$ osiągnięciach naukowych niektórych profesorów Wydziału Prawa ówczesnego Uniwersytetu Poznańskiego pisali m.in.: B. Błażejczak, Alfred Ohanowicz-początki cywilistyki poznańskiej; W. Łączkowski, Profesor Edward Taylor; Z. Ziembiński, Czesława Znamierowskiego wkład do rozwoju poznańskiego wydziału prawa; Z. Janowicz, Marian Zimmermann - uczony i człowiek; H. Olszewski, Zygmunt Wojciechowski - poznańska szkoła historii prawa - wszystkie teksty zamieszczone w: „Ruch Prawniczy, Ekonomiczny i Socjologiczny" 1994, z. 3, s. 4-23. Zob. także K. Krasowski, Wydział Prawno-Ekonomiczny Uniwersytetu Poznańskiego, w: Zarys dziejów Wydziału Prawa Uniwersytetu w Poznaniu 1919-1924, pod red. K. Krasowskiego, Poznań 2004, s. 18-32. O wkładzie polskich uczonych z tych lat w naukę światową i ich osiągnięciach w dyscyplinach humanistycznych, ekonomicznych i prawnych, jak również matematyczno-przyrodniczych pisali m.in.: A. Albert, Najnowsza historia Polski 1914-1993, t. 1, Warszawa 1995, s. 126-127; bp S. Wielgus, op. cit., s. 9.

${ }^{24}$ Zob. art. 117 Ustawy z dnia 21 III 1921 r. Konstytucja Rzeczypospolitej Polskiej (Dz.U. Nr 44, poz. 267) stanowiący, że „Badania naukowe i ogłaszanie ich wyników są wolne". Deklaracji tej nie zachowała Ustawa konstytucyjna z dnia 23 IV 1935 r. (Dz.U. Nr 30, poz. 227). Z kolei Konstytucja Rzeczypospolitej Ludowej uchwalona przez Sejm Ustawodawczy w dniu 22 VII 1952 r. (Dz.U. Nr 23, poz. 232) deklarowała dbałość państwa "O wszechstronny rozwój nauki, opartej na dorobku przodującej myśli ludzkiej i postępowej myśli polskiej - nauki w służbie narodu" (art. 63) i otoczenie szczególną opieką inteligencji twórczej - pracowników nauki" (art. 65). Tymczasem Konstytucja Rzeczypospolitej Polskiej z dnia 2 IV 1997 r. (Dz.U. Nr 78, poz. 483), w swej treści zbliżona do Konstytucji z dnia 21 III 1921 r., zapewnia każdemu „wolność [...] badań naukowych oraz ogłaszania ich wyników" (art. 73). W sprawie komentarza do art. 73 zob. Konstytucje Rzeczypospolitej Polskiej oraz komentarz do Konstytucji RP z 1997 r., pod red. J. Bocia, Wrocław 1998, s. 133-134. 
podawania i oświetlania z katedry sposobem naukowym według swojego naukowego przekonania zagadnień, wchodzących w zakres tej gałęzi wiedzy, której jest przedstawicielem". Dekret z 1947 r. od tego standardu wiele nie odbiegał. Stanowił bowiem, że "[b]adania naukowe są wolne". Dodawał jednak zarazem, że "[t]wórcza praca pozostaje pod szczególną opieką państwa". Ustawa z 1951 r. zawierała jedynie ogólne stwierdzenie, że szkoły wyższe "[...] w duchu ofiarnej służby ojczyźnie, walki o pokój i socjalizm [...] organizują i prowadzą badania naukowe", zaś ustawa z 1958 r., wyznaczając szkołom wyższym „aktywne uczestnictwo w budowaniu i umacnianiu socjalizmu w Polsce Ludowej", rolę nauki dostrzegała w prowadzeniu "twórczych badań naukowych". Z kolei ustawa z 1982 r. deklarowała jako jedno z zadań szkół wyższych prowadzenie badań naukowych podyktowanych dobrem Polskiej Rzeczypospolitej Ludowej, nacechowanej wolnością nauki i sztuki, a przez to rozwijającej wielość kierunków naukowych i artystycznych przy poszanowaniu odrębności światopoglądowych. Ta różna narracja sformułowań prawnych w zakresie wyznaczającym granice wolności naukowej bez wątpienia była znacząca. W okresie Polski międzywojnia badania naukowe pozostawiono profesorom i docentom, znawcom przedmiotu (gałęzi nauki), wolnym w poszukiwaniu i dochodzeniu prawdy oraz wyrażaniu swoich naukowych poglądów. Pierwsze lata Polski Ludowej nie przyniosły większych zmian. Władze komunistyczne zrezygnowały z przekształcania nauki na wzór sowiecki, propagowano zachowanie ideowych fundamentów nauki akademickiej (wolność badań naukowych i swoboda publikacji). Z końcem $1947 \mathrm{r}$. wprawdzie nadal podkreślano wolność nauki, zarazem jednak akcentowano potrzebę opieki nad nią ze strony państwa. Opieka ta mogła być rozumiana w różny sposób, jako starania i dbałość państwa o rozszerzanie potencjału instytucji prowadzących badania naukowe i zapewnianie im warunków do dalszego rozwoju, ale mogła też stanowić zapowiedź ideologizacji nauki. Jedno nie wykluczało drugiego. Tego zdecydowanie dowodziło stopniowe ograniczanie autonomii uczelni i osłabianie ówczesnej pozycji uczonych, a także cenzura. To, że w kolejnych latach umacniano w Polsce ideologię komunistycznych przemian, nie ulega wątpliwości. Dotknęła ona także naukę (i sztukę). Począwszy od 1951 r., wyniki badań naukowych, w tym te na stopień naukowy (zgodnie z nomenklatura radziecką) i tytuł naukowy (koordynowane przez zależną od władz Centralną Komisję Kwalifikacyjną dla Pracowników Nauki), mierzono także miarą lojalności badaczy wobec państwa i narodu (w istocie 
wobec ówczesnych władz rządowych i partyjnych). Tej tendencji wiele nie zmieniła śmierć Stalina w $1953 \mathrm{r}^{25}$, choć z pewnością nastąiło pewne osłabienie nacisków ideologicznych na naukę. Od wartości wtedy uznawanych za priorytetowe - ideologizacji nauki podporządkowanej potrzebom państwa socjalistycznego (pragmatyzującym politykę naukową) - w żadnym razie jednak nie odstąpiono. Obecna w nauce doktryna marksistowska narzucała schematy ideologiczne i metodologiczne w doborze tematyki badań i osiąganych wyników przez wyselekcjonowane (najczęściej partyjnie) zespoły naukowców. Coraz wyraźniej zaznaczało się odchodzenie od etosu ludzi nauki i pojmowanie nauki jako instrumentu potrzebnego ówczesnej władzy nie tylko w procesie kształtowania marksistowskich postaw światopoglądowych $\mathrm{w}$ nauce, ale i poza nią ${ }^{26}$. Naukę podporządkowano potrzebom społeczeństwa socjalistycznego w dziedzinie gospodarki, kultury, oświaty i warunków życia człowieka ${ }^{27}$. Tym samym poddawano ją bądź procesowi swoistej industrializacji przez wprowadzanie do niej wzorców z życia gospodarczego i prowadzenie badań podstawowych (wdrożeniowych), bądź procesowi jej reindustrializacji przez podejmowanie badań na rzecz zbiorowości społecznych. Dopiero okres po 1989 r. cechuje odejście od ideologizacji i upaństwowienia nauki na rzecz poszukiwania wzorców uniwersalnych i ugruntowania praktyki podejmowania tematów badawczych bez ideologicznego spojrzenia.

${ }^{25}$ Jak dalece śmierć Stalina uwidoczniła w ocenie ówczesnych najwyższych władz państwowych jego zasługi dla Polski, dowodzi m.in. Uchwała Rady Państwa i Rady Ministrów Polskiej Rzeczypospolitej Ludowej z dnia 7 III 1953 r. o uczczeniu pamięci Józefa Stalina (M.P. Nr 23, poz. 280), którą obie władze rządzące "[d]la uczczenia pamięci Wielkiego Wodza i Nauczyciela mas pracujących i Jego wiekopomnych zasług dla Polski" m.in. uchwaliły „[z]godnie z wnioskiem Komitetu Wojewódzkiego Polskiej Zjednoczonej Partii Robotniczej, Prezydium Wojewódzkiej Rady Narodowej, Prezydium Miejskiej Rady Narodowej i Wojewódzkiego Komitetu Frontu Narodowego w Katowicach, miasto Katowice przemianować na miasto STALINOGRÓD, a województwo katowickie na województwo STALINOGRODZKIE".

${ }^{26}$ Zgodnie z uchwałą II Kongresu Nauki Polskiej osiągnięto wyznaczony uchwałą I Kongresu Nauki Polskiej zwołanego w 1951 r. cel strategiczny, jakim było zwycięstwo teorii marksistowsko-leninowskiej jako orientacji metodologicznej, Uchwała II Kongresu Nauki Polskiej, "Życie Szkoły Wyższej” 1973, nr 7-8, s. 3. "Jedyny tytuł do szacunku społecznego daje ideowa postawa i rzetelna praca w każdym zawodzie i na każdym posterunku" - słowa zaczerpnięte z Przemówienia I Sekretarza KC PZPR Edwarda Gierka na Centralnej inauguracji roku akademickiego w Katowicach, "Życie Szkoły Wyższej” 1974, nr 12, s. 6.

${ }_{27}$ Zgodnie z Uchwałą VI Zjazdu PZPR, przywołaną w apelu przez uczonych polskich, Apel uczonych polskich do pracowników nauki, oświaty i kultury, "Życie Szkoły Wyższej” 1973, nr 1, s. 3. 


\section{Tytuły profesora w Polsce międzywojennej}

W pierwszych latach Polski międzywojnia nominacje profesorskie podporządkowano przede wszystkim motywom racjonalnym, podyktowanym potrzebą zagwarantowania poszczególnym katedrom kadry profesorskiej właściwej ze względu na im odpowiadający zakres naukowy i dydaktyczny. Początkowo temu celowi służyła wyłącznie instytucja mianowania profesorów przez Naczelnika Państwa w drodze dekretu lub postanowienia ${ }^{28}$. Od $1920 \mathrm{r}$. do osiągnięcia tego celu prowadziły dwie drogi: (1) nadanie tytułu profesora zwyczajnego lub profesora nadzwyczajnego oraz (2) mianowanie profesora w zakresie danego przedmiotu (gałęzi nauki, choć tego terminu nie użyto). W rzeczywistości nadawanie tytułu profesora (zwyczajnego i nadzwyczajnego) było sporadyczne, naczelna władza państwowa nadawała je do połowy 1923 r. Po tym czasie powrócono do wzorów wcześniejszych - instytucji mianowania profesorów. I od tej praktyki nie odstąpiono do końca II Rzeczypospolitej.

Tytuł profesora zwyczajnego mógł być nadany profesorowi nadzwyczajnemu, jeżeli jego dorobek naukowy powiększył się w czasie profesury nadzwyczajnej ${ }^{29}$, choć nie było to regułą ${ }^{30}$, a tytuł profesora

${ }^{28}$ Przykładowo, Naczelnik Państwa zamianował w drodze dekretu (bez podania daty) dra Leona Petrażyckiego, profesora Uniwersytetu Petersburskiego, ostatnio wykładającego w Uniwersytecie Warszawskim, profesorem zwyczajnym socjologii na Wydziale Prawa i Nauk Politycznych tegoż Uniwersytetu, oraz dra Tadeusza Kotarbińskiego, dotychczasowego wykładowcy w Uniwersytecie Warszawskim, profesorem nadzwyczajnym filozofii w tymże uniwersytecie; Postanowieniem z dnia 14 V 1919 r.: profesora nadzwyczajnego dra Kazimierza Kumanieckiego profesorem zwyczajnym prawa administracyjnego, nauki administracji i statystyki Uniwersytetu Jagiellońskiego; docenta prywatnego dra Józefa Janowskiego profesorem nadzwyczajnym historii literatury ruskiej i rosyjskiej Uniwersytetu Jagiellońskiego; Postanowieniem z dnia $26 \mathrm{~V}$ 1919 r. nadzwyczajnego bezpłatnego profesora Uniwersytetu Lwowskiego dra Romana Negrusza profesorem nadzwyczajnym fizyki z pełnymi poborami, z ważnością od 1 IV 1919 r. (Dz.Urz. MWRiOP 1919, Nr 6, poz. 18).

${ }^{29}$ Zob. np. Postanowienie Naczelnika Państwa z dnia 24 VIII 1921 r. nadające drowi Maurycemu Allerhardowi, docentowi prawa procesowego cywilnego z tytułem nadzwyczajnego profesora w Uniwersytecie Jana Kazimierza we Lwowie, tytuł zwyczajnego profesora Uniwersytetu (Dz.Urz. MWRiOP Nr 19, poz. 200).

${ }^{30}$ Zob. np. Postanowienie z dnia 6 VII 1920 r., którym Naczelnik Państwa nadał doktorowi Fryderykowi Papéemu, dyrektorowi Biblioteki Jagiellońskiej w Krakowie, docentowi historii w Uniwersytecie Jagiellońskim w Krakowie, tytuł profesora zwyczajnego (Dz.Urz. MWRiOP Nr 22, poz. 146); Postanowienie z dnia 23 VIII 1920 r., którym Naczelnik Państwa nadał drowi Bolesławowi Mańkowskiemu, docentowi prywatnemu 
nadzwyczajnego - docentowi ${ }^{31}$ (bez wskazania przesłanek warunkujących jego nadanie). Prawo ich nadawania pozostawiono do połowy marca 1923 r. w gestii Naczelnika Państwa, później Prezydenta Rzeczypospolitej. Naczelnik Państwa tytuły te nadawał na wniosek Rady Ministrów, przedstawiony jej przez ministra wyznań religijnych i oświecenia publicznego ${ }^{32}$. W tym samym trybie, lecz już przy zachowaniu warunków określonych ustawą z dnia 13 lipca 1920 r. ${ }^{33}$, mianował on także profesorów. Kompetencje Naczelnika Państwa w zakresie nadawania tytułów profesora oraz mianowania profesorów od drugiej połowy marca 1923 r. należały do Prezydenta Rzeczypospolitej Polskiej.

Ustawa z roku 1933 wprawdzie zachowała tytuły profesora zwyczajnego i nadzwyczajnego (także inne tytuły profesora), ich przyznawanie przewidywała jednak wyłącznie w drodze nominacji. Profesorów mianował Prezydent na wniosek ministra wyznań religijnych i oświecenia publicznego, po porozumieniu z Prezesem Rady Ministrów ${ }^{34}$,

pedagogiki, dyrektorowi Biblioteki Uniwersytetu Jana Kazimierza we Lwowie, tytuł profesora zwyczajnego (Dz.Urz. MWRiOP Nr 22, poz. 146).

${ }^{31}$ Postanowienie Naczelnika Państwa z dnia 16 III 1920 r. nadające prywatnemu docentowi geologii i paleontologii, drowi Wojciechowi Rogali, tytuł profesora nadzwyczajnego (Dz.Urz. MWRiOP Nr 7, poz. 56); Postanowienie Naczelnika Państwa z dnia 6 VIII 1920 r. nadające drowi Alfredowi Rosenblattowi, prywatnemu docentowi matematyki Uniwersytetu Jagiellońskiego w Krakowie, tytuł profesora nadzwyczajnego matematyki (Dz.Urz. MWRiOP Nr 22, poz. 146); Postanowienie Prezydenta Rzeczypospolitej z dnia 31 VII 1923 r. nadające docentce dr Michalinie Stefanowskiej - tytuł profesorki nadzwyczajnej na wydziale lekarskim w Uniwersytecie Poznańskim (Dz.Urz. MWRiOP Nr 19, poz. 178).

32 Po raz pierwszy Prezydent Rzeczypospolitej nadał, w drodze postanowienia z dnia 22 V 1923 r., tytuł nadzwyczajnego profesora Uniwersytetu docentowi Uniwersytetu Jana Kazimierza we Lwowie drowi Tadeuszowi Ostrowskiemu (Dz.Urz. MWRiOP Nr 14, poz. 131).

${ }^{33}$ Po zatwierdzeniu przez zebranie ogólne profesorów lub senat wniosków rad wydziałowych o powołaniu profesorów zwyczajnych, nadzwyczajnych i honorowych i przedstawieniu ich ministrowi wyznań religijnych i oświecenia publicznego - art. 12 pkt 4 i art. 19 pkt 19 Ustawy z dnia 13 VII 1920 r. o szkołach akademickich.

${ }^{34}$ Zob. art. 3 ust. 1 Rozporządzenia Prezydenta Rzeczypospolitej z dnia 24 II 1928 r. o stosunku służbowym profesorów państwowych szkół akademickich i pomocniczych sił naukowych, w brzmieniu nadanym tekstem jednolitym z 1933 r. (Obwieszczenie Ministra Wyznań Religijnych i Oświecenia Publicznego z dnia 21 VII 1933 r. w sprawie ogłoszenia jednolitego tekstu rozporządzenia Prezydenta Rzeczypospolitej z dnia 24 II 1928 r. o stosunku służbowym profesorów państwowych szkół akademickich i pomocniczych sił naukowych tych szkół (Dz.U. Nr 76, poz. 551). 
z zastrzeżeniem przewidzianym ustawą. Minister mógł bowiem, na wniosek rady wydziałowej, przedstawić tylko tego profesora nadzwyczajnego do nominacji na profesora zwyczajnego, którego dorobek naukowy (artystyczny) wydatnie się powiększył w czasie profesury nadzwyczajnej.

Tym samym Naczelnik Państwa / Prezydent Rzeczypospolitej mianował: (1) profesorów honorowych ${ }^{35}$ (przy zachowaniu tego tytułu wyłącznie dla wybitnych uczonych z grona profesorów, ustępujących z katedr ${ }^{36}$ ), ale mógł też profesora honorowego danej uczelni mianować profesorem zwyczajnym w innej uczelni ${ }^{37}$; (2) zastępców profesora (instytucja mająca charakter wyjątkowy, uzasadniony ustąpieniem profesora $\mathrm{z}$ katedry

${ }^{35}$ Mianowanie profesora honorowego (z powodu osiągnięcia 65. roku życia) należało do władzy naczelnej państwowej na podstawie wniosku rady wydziałowej, przyjętego przez zebranie ogólne względnie senat i przedstawionego ministrowi wyznań religijnych i oświecenia publicznego. Mianowany profesor honorowy nie tracił veniam legendi (1920). Profesorowie ustępujący z katedr dobrowolnie lub z powodu przekroczenia granicy wieku, których nie mianowano profesorami honorowymi, zachowywali prawo korzystania z zakładów szkoły w ramach regulaminu zakładowego, tracili natomiast prawo wykładania. Minister mógł im jednak to prawo przywrócić (1933)

${ }^{36}$ Przykładowo, Naczelnik Państwa z dniem 1 IV 1920 r. mianował dra Ignacego Zakrzewskiego, emerytowanego profesora zwyczajnego Uniwersytetu Jana Kazimierza we Lwowie, profesorem honorowym (Dz.Urz. MWRiOP Nr 11, poz. 83). Zob. też: Postanowienie Naczelnika Państwa z dnia 31 III 1922 r. mianujące dra Tadeusza Herynga profesorem honorowym Uniwersytetu Warszawskiego (Dz.Urz. MWRiOP Nr 20, poz. 220); Postanowienie Marszałka Sejmu w zastępstwie Prezydenta Rzeczypospolitej mianujące z dniem 2 VI 1926 r. profesora dra Ignacego Mościckiego, profesora zwyczajnego Politechniki Lwowskiej, profesorem honorowym tejże Politechniki (Dz.Urz. MWRiOP Nr 12, poz. 155); Postanowieniem z dnia 19 XI 1929 r. Prezydent Rzeczypospolitej mianował Karola Appla, emerytowanego zwyczajnego profesora językoznawstwa ogólnego w Uniwersytecie Warszawskim, profesorem honorowym tegoż uniwersytetu (Dz.Urz. MWRiOP Nr 1, poz. 9).

${ }^{37}$ Zob. np.: Postanowienie Naczelnika Państwa z dnia 24 VIII 1921 r. mianujące dra Bolesława Erzepkiego, dyrektora Muzeum im. Mielżyńskich w Poznaniu, profesorem honorowym starszej filologii polskiej w Uniwersytecie Poznańskim (Dz.Urz. MWRiOP Nr 19, poz. 200); Postanowienie Prezydenta Rzeczypospolitej z dnia 22 V 1923 r. mianujące byłego profesora zwyczajnego i profesora honorowego dra Leona Pińskiego - profesorem zwyczajnym prawa rzymskiego na wydziale prawa i umiejętności politycznych w Uniwersytecie Jana Kazimierza we Lwowie (Dz.Urz. MWRiOP Nr 15, poz. 144); Postanowienie Prezydenta Rzeczypospolitej z dnia 25 VIII 1923 r. mianujące zwyczajnego profesora Uniwersytetu Jana Kazimierza we Lwowie dra Józefa Markowskiego profesorem honorowym Uniwersytetu Poznańskiego (Dz.Urz. MWRiOP Nr 21, poz. 193). 
lub innym ważnym powodem skutkującym przerwą w wykładach z jakiegoś przedmiotu ${ }^{38}$ ), a także (3) profesorów tytularnych ${ }^{39}$.

Gros mianowanych profesorów należało jednak do innej grupy profesorów właściwych z danego przedmiotu (gałęzi wiedzy) ${ }^{40}$, niekiedy

${ }^{38}$ Zob. np.: Postanowienie Naczelnika Państwa z dnia 24 VIII 1921 r. mianujące zastępcę profesora, dyrektora Wiktora Grzywo-Dąbrowskiego, nadzwyczajnym profesorem medycyny sądowej w Uniwersytecie Warszawskim z ważnością od dnia 1 X $1921 \mathrm{r}$. (Dz.Urz. MWRiOP Nr 19, poz. 200); Postanowienie Naczelnika Państwa z dnia 27 VIII 1921 r. mianujące inż. Oskara Nowotnego, byłego adiunkta i zastępcę profesora Akademii Górniczej w Leoben, profesorem zwyczajnym geodezji i miernictwa podziemnego w Akademii Górniczej w Krakowie (Dz.Urz. MWRiOP Nr 19, poz. 200); Postanowienie Naczelnika Państwa z dnia 16 VI 1922 r. mianujące zastępcę profesora, mgr Stanisława Kalandyka, profesorem zwyczajnym fizyki na wydziale lekarskim Uniwersytetu Poznańskiego, oraz Postanowienie Naczelnika Państwa z dnia 28 VI 1922 r. mianujące zastępcę profesora dra Władysława Mierzejewskiego, profesorem nadzwyczajnym anatomii porównawczej na wydziale matematyczno-przyrodniczym Uniwersytetu Stefana Batorego w Wilnie (Dz.Urz. MWRiOP Nr 26, poz. 294); Postanowienie Prezydenta Rzeczypospolitej z dnia 19 XI 1929 r. mianujące dr Helenę Antoninę z Grabowskich Willmanowa, zastępcę profesora Uniwersytetu Jagiellońskiego w Krakowie, profesorem nadzwyczajnym sanskrytu i filologii indyjskiej na wydziale filozoficznym tegoż Uniwersytetu (Dz.Urz. MWRiOP 1930 Nr 1, poz. 9); Postanowienie Prezydenta Rzeczypospolitej z dnia 4 XII 1929 r. mianujące dra Włodzimierza Gorjaczkowskiego, docenta i zastępcę profesora, profesorem nadzwyczajnym sadownictwa na Wydziale Ogrodniczym Szkoły Głównej Gospodarstwa Wiejskiego w Warszawie (Dz.Urz. MWRiOP Nr 2, poz. 21).

${ }^{39}$ Zgodnie z art. 32 ustawy z 1933 r. Prezydent Rzeczypospolitej mógł na wniosek ministra wyznań religijnych i oświecenia publicznego, przedstawiony na podstawie uchwały rady wydziałowej i po wysłuchaniu opinii senatu, mianować tytularnymi profesorami szkoły akademickiej za wybitną działalność naukową (artystyczną) docentów, którzy wykładali w tym charakterze co najmniej pięć lat. Zob. np. Postanowienie Prezydenta Rzeczypospolitej z dnia 6 XI 1931 r. mianujące dra Aleksandra Safarewicza, docenta Uniwersytetu Stefana Batorego w Wilnie, profesorem tytularnym na Wydziale Lekarskim tegoż uniwersytetu (Dz.Urz. MWRiOP Nr 12, poz. 139); Postanowienie Prezydenta Rzeczypospolitej mianujące z dniem 19 IV 1938 r. Jana Marcelego Fabre profesorem tytularnym na Wydziale Humanistycznym Uniwersytetu J. Piłsudskiego w Warszawie (Dz.Urz. MWRiOP Nr 5, poz. 141).

${ }^{40}$ Postanowienie Naczelnika Państwa z dnia 10 II 1920 r. mianujące profesora nadzwyczajnego dra Antoniego Cieszyńskiego profesorem zwyczajnym stomatologii i dentystyki w Uniwersytecie Jana Kazimierza we Lwowie (Dz.Urz. MWRiOP Nr 5, poz. 45); Postanowienie Naczelnika Państwa z dnia 16 III 1920 r. mianujące nadzwyczajnego profesora pediatrii, dra Franciszka Groera, profesorem zwyczajnym pediatrii w Uniwersytecie Jana Kazimierza we Lwowie (Dz.Urz. MWRiOP Nr 7, poz. 56); Postanowienie z dnia 9 IV 1920 r. mianujące profesora nadzwyczajnego filologii klasycznej w Uniwersytecie Warszawskim, dra Gustawa Przychockiego, profesorem zwyczajnym tegoż przedmiotu (Dz.Urz. MWRiOP Nr 12, poz. 91); Postanowienie Naczelnika Państwa z dnia 21 IV 1920 r. mianujące dotychczasowego profesora nadzwyczajnego, inż. Leona Karasińskiego, profesorem zwyczajnym mechaniki technicznej w Politechnice Warszawskiej 
z zakresu rozszerzonego bez zmiany macierzystej uczelni ${ }^{41}$ bądź jednocześnie z jej zmianą ${ }^{42}$. Wyjątku nie stanowiło także mianowanie

(Dz.Urz. MWRiOP Nr 12, poz. 91); Postanowienie Naczelnika Państwa z dnia 10 VI 1921 r. mianujące nadzwyczajnego profesora, dra Alfreda Ohanowicza, zwyczajnym profesorem prawa cywilnego w Uniwersytecie Poznańskim (Dz.Urz. MWRiOP 1921 Nr 19, poz. 200); Postanowienie Naczelnika Państwa z dnia 10 VI 1921 r. mianujące nadzwyczajnego profesora, dra Edwarda Taylora, zwyczajnym profesorem ekonomii i skarbowości w Uniwersytecie Poznańskim (Dz.Urz. MWRiOP 1921 Nr 19, poz. 200); Postanowienie Naczelnika Państwa z dnia 27 VIII 1921 r. mianujące profesora nadzwyczajnego matematyki w Politechnice Lwowskiej, dra Antoniego Lomnickiego, zwyczajnym profesorem tegoż przedmiotu (Dz.Urz. MWRiOP Nr 19, poz. 200); Postanowienie Naczelnika Państwa z dnia 3 IX 1921 r. mianujące profesora nadzwyczajnego, dra Kazimierza Tymanieckiego, profesorem zwyczajnym historii średniowiecznej w Uniwersytecie Poznańskim (Dz.Urz. MWRiOP Nr 19, poz. 200).

${ }^{41}$ Zob. np. Postanowienie Naczelnika Państwa z dnia 26 VII 1922 r. mianujące dra Romana Longchamp de Berier, profesora nadzwyczajnego Uniwersytetu Jana Kazimierza we Lwowie, profesorem zwyczajnym prawa cywilnego tegoż Uniwersytetu (Dz.Urz. MWRiOP Nr 32, poz. 433); Postanowienie Naczelnika Państwa z dnia 9 X 1922 r. mianujące profesora zwyczajnego historii średniowiecznej w Uniwersytecie Poznańskim, dra Kazimierza Tymienieckiego, profesorem zwyczajnym historii gospodarczej i społecznej na Wydziale Filozoficznym w Uniwersytecie Warszawskim (Dz.Urz. MWRiOP Nr 32, poz. 433); Postanowienie Prezydenta Rzeczypospolitej z dnia 10 II 1928 r. mianujące J.E. ks. Biskupa dra Michała Godlewskiego profesorem zwyczajnym w Uniwersytecie Jagiellońskim w Krakowie (Dz.Urz. MWRiOP Nr 3, poz. 62); Postanowienie Prezydenta Rzeczypospolitej z dnia 19 XI 1929 r. mianujące dra Wacława Oraczewskiego, profesora zwyczajnego chemii w Akademii Medycyny Weterynaryjnej we Lwowie, profesorem zwyczajnym patologii ogólnej i chemii lekarskiej w tejże Akademii (Dz.Urz. MWRiOP Nr 1, poz. 9).

42 Postanowienie Naczelnika Państwa z dnia 15 IV 1920 r. mianujące profesora zwyczajnego filologii słowiańskiej w Uniwersytecie Jana Kazimierza we Lwowie, dra Kazimierza Nitscha, profesorem zwyczajnym językoznawstwa słowiańskiego w Uniwersytecie Jagiellońskim w Krakowie, z ważnością od dnia 1 IV 1920 r. (Dz.Urz. MWRiOP Nr 12, poz. 91); Postanowienie Naczelnika Państwa z dnia 1 VII 1920 r. mianujące doktora Kazimierza Noiszewskiego, docenta prywatnego Akademii medycznej wojskowej w Petersburgu, profesorem zwyczajnym okulistyki w Uniwersytecie Warszawskim (Dz.Urz. MWRiOP Nr 22, poz. 146); Postanowienie Naczelnika Państwa z dnia 22 IX 1920 r. mianujące profesora Akademii Weterynarii we Lwowie i Podsekretarza Stanu w Ministerstwie Spraw Zagranicznych, dra Stefana Dąbrowskiego, zwyczajnym profesorem chemii na Wydziale lekarskim w Uniwersytecie Poznańskim (Dz.Urz. MWRiOP Nr 19, poz. 200); Postanowienie Naczelnika Państwa z dnia 21 I 1922 r. mianujące profesora zwyczajnego filologii słowiańskiej w Uniwersytecie Poznańskim, dra Tadeusza Lehr-Spławińskiego, zwyczajnym profesorem filologii słowiańskiej w Uniwersytecie Jana Kazimierza we Lwowie (Dz.Urz. MWRiOP Nr 20, poz. 220); Postanowienie Naczelnika Państwa z dnia 31 VIII 1921 r. mianujące profesora zwyczajnego Uniwersytetu Jagiellońskiego w Krakowie, Czesława Białobrzeskiego, profesorem zwyczajnym fizyki teoretycznej w Uniwersytecie Warszawskim (Dz.Urz. MWRiOP Nr 19, poz. 390); Postanowienie Naczelnika Państwa z dnia 15 VII 1922 r. mianujące profesora nadzwyczajnego teorii i historii sztuki w Uniwersytecie Poznańskim, dra Władysława Tatarkiewicza, profesorem 
przez Naczelnika Państwa / Prezydenta Rzeczypospolitej profesorów z wyższym stopniem naukowym i veniam legendi ${ }^{43}$ bądź bez habilitacji ${ }^{44}$, ale też i z niższym stopniem naukowym ${ }^{45}$. W tym zakresie ów „ruch

nadzwyczajnym filozofii w Uniwersytecie Warszawskim (Dz.Urz. MWRiOP Nr 32, poz. 433); Postanowienie Prezydenta Rzeczypospolitej z dnia 12 IX 1923 r. mianujące profesora nadzwyczajnego Politechniki Lwowskiej, dra Mariana Górskiego, profesorem zwyczajnym uprawy roli i nawożenia na wydziale rolniczym Szkoły Głównej Gospodarstwa Wiejskiego w Warszawie (Dz.Urz. MWRiOP Nr 21, poz. 193); Postanowienie Prezydenta Rzeczypospolitej z dnia 3 III 1928 r. mianujące dra Kazimierza Ajdukiewicza, profesora nadzwyczajnego w Uniwersytecie Warszawskim, profesorem nadzwyczajnym filozofii w Uniwersytecie Jana Kazimierza we Lwowie (Dz.Urz. MWRiOP Nr 4, poz. 86).

${ }^{43}$ Zob. np. Postanowienie Naczelnika Państwa z dnia 21 I 1920 r. mianujące docenta prywatnego Uniwersytetu Lwowskiego z tytułem nadzwyczajnego profesora, byłego wykładającego w Uniwersytecie Warszawskim i byłego Ministra Wyznań Religijnych i Oświecenia Publicznego, dra Jana Łukaszewicza, profesorem zwyczajnym filozofii (Dz.Urz. MWRiOP Nr 11, poz. 83); Postanowienie Naczelnika Państwa z dnia 28 II 1920 r. mianujące docenta filologii biblijnej, księdza Jana Stawarczyka, profesorem nadzwyczajnym tegoż przedmiotu (Dz.Urz. MWRiOP Nr 5, poz. 45); Postanowienie Naczelnika Państwa z dnia 11 VI 1920 r. mianujące dra Franciszka Bossowskiego, docenta prywatnego Uniwersytetu Jagiellońskiego w Krakowie, profesorem nadzwyczajnym prawa rzymskiego w Uniwersytecie Stefana Batorego w Wilnie (Dz.Urz. MWRiOP Nr 19, poz. 127); Postanowienie Naczelnika Państwa z dnia 1 VII 1920 r. mianujące dra Kazimierza Noiszewskiego, docenta prywatnego Akademii Medycznej wojskowej w Petersburgu, profesorem zwyczajnym okulistyki w Uniwersytecie Warszawskim (Dz.Urz. MWRiOP Nr 22, poz. 146); Postanowienie Naczelnika Państwa z dnia 22 IX 1920 r. mianujące dr Helenę Gajewska, docentkę Uniwersytetu Jagiellońskiego w Krakowie, profesorką nadzwyczajną histologii na Wydziale Lekarskim w Uniwersytecie Poznańskim, z ważnością od dnia 1 X 1920 r. (Dz.Urz. MWRiOP Nr 22, poz. 146); Postanowienie Prezydenta Rzeczypospolitej z dnia 4 XII 1928 r. mianujące dra Janusza Paneikę, docenta Uniwersytetu Jagiellońskiego w Krakowie, profesorem nadzwyczajnym prawa administracyjnego w Uniwersytecie Stefana Batorego w Wilnie; Postanowienie Prezydenta Rzeczypospolitej z dnia 25 I 1939 r. mianujące dra Antoniego Żabko-Potowicz, docenta Szkoły Głównej Gospodarstwa Wiejskiego, profesorem nadzwyczajnym polityki ekonomicznej na Wydziale leśnym tejże szkoły (Dz.Urz. MWRiOP Nr 2, poz. 62).

${ }^{44}$ Postanowienie Naczelnika Państwa z dnia 8 VI 1920 r. mianujące dra Walerego Goetla profesorem nadzwyczajnym geologii i paleontologii w Akademii Górniczej w Krakowie (Dz.Urz. MWRiOP Nr 19, poz. 127); Postanowienie Naczelnika Państwa z dnia 29 III 1922 r. mianujące kierownika Państwowego Zakładu epidemiologicznego w Łodzi, dra Franciszka Venuletta, profesorem zwyczajnym patologii ogólnej i doświadczalnej w Uniwersytecie Warszawskim (Dz.Urz. MWRiOP Nr 20, poz. 220); Postanowienie Prezydenta Rzeczypospolitej z dnia 30 IX 1923 r. mianujące dra Bronisława Antoniego Stelmachowskiego profesorem nadzwyczajnym procesu cywilnego na wydziale prawa i nauk ekonomiczno-politycznych w Uniwersytecie Poznańskim (Dz.Urz. MWRiOP Nr 21, poz. 193).

${ }^{45}$ Zob. np.: Postanowienie Naczelnika Państwa z dnia 20 III 1920 r. mianujące mgra praw Konrada Dynowskiego, byłego docenta Uniwersytetu Petersburskiego i profesora prawa i procedury cywilnej w Liceum Aleksandrowskim w Petersburgu, profesorem 
służbowy", wsparty instytucją prawną mianowania, pozwalał kadrze naukowej na dość dużą elastyczność w zmianie miejsca zatrudnienia, zwykle powodowaną różnymi racjami. Z jednej strony uzasadnioną opróżnieniem katedry przez profesora nią kierującego (kierowanie

zwyczajnym postępowania sądowego cywilnego w Uniwersytecie Warszawskim (Dz.Urz. MWRiOP Nr 12, poz. 91); Postanowienie Naczelnika Państwa z dnia 9 IV 1920 r. mianujące artystę malarza Stanisława Kamockiego profesorem nadzwyczajnym nauki krajobrazu w Uniwersytecie Warszawskim (Dz.Urz. MWRiOP Nr 11, poz. 83); Postanowienie Naczelnika Państwa z dnia 21 IV 1920 r. mianujące mgra prawa i administracji, prof. Alfonsa Parczewskiego, profesora honorowego Uniwersytetu Warszawskiego i byłego Dziekana Wydziału prawa i nauk politycznych w tym Uniwersytecie, profesorem zwyczajnym prawa kanonicznego na Wydziale prawa i nauk społecznych w Uniwersytecie Stefana Batorego w Wilnie (Dz.Urz. MWRiOP Nr 12, poz. 91); Postanowienie Naczelnika Państwa z dnia 3 VIII 1920 r. mianujące Jana Gordziałkowskiego, mgra medycyny weterynaryjnej, byłego profesora w Instytucie Weterynaryjnym w Charkowie, profesorem zwyczajnym chorób zakaźnych studium weterynaryjnego w Uniwersytecie Warszawskim (Dz.Urz. MWRiOP Nr 22, poz. 146); Postanowienie Naczelnika Państwa z dnia 22 VIII 1921 r. mianujące Rektora Wolnej Wszechnicy Polskiej, Stanisława Kalinowskiego, nadzwyczajnym profesorem fizyki doświadczalnej w Politechnice Warszawskiej z ważnością nominacji od dnia 1 IX 1921 r. (Dz.Urz. MWRiOP Nr 19, poz. 200); Postanowienie Naczelnika Państwa z dnia 3 IX 1921 r. mianujące inż. Kazimierza Zipsera, szefa Sekcji w Ministerstwie Kolei Żelaznych, profesorem zwyczajnym kolejnictwa w Politechnice Lwowskiej (Dz.Urz. MWRiOP Nr 19, poz. 200); Postanowienie Naczelnika Państwa z dnia 16 VI 1922 r. mianujące mgra zoologii Wacława Baehra, profesorem zwyczajnym cytologii ad personam na wydziale filozoficznym Uniwersytetu Warszawskiego (Dz.Urz. MWRiOP Nr 26, poz. 294); Postanowienie Naczelnika Państwa z dnia 22 VIII 1922 r. mianujące inż. górniczego Kazimierza Kasińskiego profesorem zwyczajnym górnictwa II w Akademii Górniczej w Krakowie (Dz.Urz. MWRiOP Nr 32, poz. 433); Postanowienie Prezydenta Rzeczypospolitej z dnia 22 XII 1922 r. mianujące dyrektora kopalni naftowych w Borysławiu, inż. Zygmunta Syriusz-Bielskiego, profesorem zwyczajnym górnictwa naftowego na wydziale górniczym Akademii Górniczej w Krakowie (Dz.Urz. MWRiOP Nr 2, poz. 24); dwa Postanowienia Prezydenta Rzeczypospolitej z dnia 9 VII 1923 r. mianujące: pierwsze - inż. Karola Taylora profesorem zwyczajnym silników spalinowych na wydziale mechanicznym Politechniki Warszawskiej, drugie - mgr Jana Kazimierza-Włodzimierza Muszyńskiego - profesorem nadzwyczajnym farmakologii i hodowli roślin lekarskich na wydziale lekarskim Uniwersytetu Stefana Batorego; Postanowienie Prezydenta Rzeczypospolitej z dnia 23 VII 1923 r. mianujące profesora Uniwersytetu Poznańskiego Bohdana Wasiutyńskiego profesorem nadzwyczajnym administracji i prawa administracyjnego na wydziale prawa i nauk politycznych w Uniwersytecie Warszawskim (Dz.Urz. MWRiOP Nr 19, poz. 178); Postanowienie Prezydenta Rzeczypospolitej z dnia 24 X 1923 r. mianujące byłego Ministra Skarbu Wladysława Grabskiego profesorem zwyczajnym polityki ekonomicznej w Szkole Głównej Gospodarstwa Wiejskiego w Warszawie (Dz.Urz. MWRiOP Nr 21, poz. 193); Postanowienie Prezydenta Rzeczypospolitej mianujące inż. Marcelego Struszyńskiego profesorem nadzwyczajnym analizy technicznej i towaroznawstwa na Wydziale Chemii Politechniki Warszawskiej z dniem 24 VII 1938 r. (Dz.Urz. MWRiOP Nr 9, poz. 285). 
katedrą w istocie było dożywotnie) i awansem w karierze naukowej (nie zawsze motywowanym powyższym jedynie względem). $Z$ drugiej strony uwarunkowaną dość wygodnym instrumentem, skutecznie służącym rozmieszczaniu kadr naukowych. Bez wątpienia tendencjom tym sprzyjała ograniczona liczba kadry profesorskiej tych lat.

Począwszy od 1920 r., wybór kandydujących do tytułów profesorskich nie był jednak swobodny ani prosty. Ówczesne przepisy dotyczące organizacji szkół akademickich dla skuteczności mianowania wymagały zachowania określonego trybu postępowania: wniosku rady wydziałowej przyjętego przez zebranie ogólne profesorów lub senat $\left(1920^{46}\right)$, senat $\left(1933^{47}\right)$ i jego przedstawienia ministrowi wyznań religijnych

${ }^{46}$ Z mocy ustawy z dnia 13 VII 1920 r. państwowa szkoła akademicka (co najmniej dwuwydziałowa) mogła w drodze statutu szczegółowego do swej struktury organizacyjnej wprowadzić, poza senatem jako organem obowiązkowym, zebranie ogólne profesorów jako hierarchicznie najwyższą władzę (w państwowych szkołach akademickich jednowydziałowych zwykle były to rady profesorów. Radę profesorów przewidywał m.in. statut Szkoły Głównej Gospodarstwa Wiejskiego w Warszawie z dnia 7 II 1919 r., Dz.Urz. MWRiOP Nr 2, poz. 7). Jeśli uczelnia z tego prawa skorzystała, do zebrania ogólnego profesorów (rady profesorów) należało m.in. „zatwierdzanie wniosków rad wydziałowych o powołaniu profesorów zwyczajnych, nadzwyczajnych, honorowych [...] i przedstawianie ich ministerstwu wyznań religijnych i oświecenia publicznego do zatwierdzenia" (art. 12 pkt 4). W tych zaś szkołach wielowydziałowych, w których statut szczegółowy szkoły nie przewidywał zebrania ogólnego profesorów, kompetencje $\mathrm{w}$ tym zakresie przysługiwały senatowi - z wyłączeniem kompetencji w zakresie wyboru rektora (art. 19 pkt 19). Statuty ówczesnych państwowych szkół akademickich polskich przewidywały różne w tym zakresie rozwiązania. Przed rokiem 1920 z reguły tymczasowymi statutami namiastkę późniejszego ogólnego zebrania profesorów wprowadzano poprzez określenie pierwszego składu profesorów w danym uniwersytecie. Zob. np.: Dekret z dnia 7 I 1919 r. w sprawie mianowania pierwszego składu profesorów w Uniwersytecie Warszawskim (Dz.Praw PP nr 5, poz. 94); Dekret z dnia 8 I 1919 r. w sprawie mianowania pierwszego składu profesorów w Politechnice Warszawskiej (Dz.Urz. MWRiOP Nr 1, poz. 6); Tymczasowy statut Uniwersytetu Stefana Batorego w Wilnie, wprowadzony Rozkazem Naczelnego Wodza Wojsk Polskich z dniem 11 X 1919 r. (Dz.Urz. MWRiOP Nr 10-11, poz. 2 ze zm.). Z lat późniejszych zob. np. Rozporządzenie Ministra Wyznań Religijnych i Oświecenia Publicznego z dnia 23 VI 1934 r. w sprawie ustalenia pierwszego składu zebrania ogólnego profesorów i grona nauczycieli akademickich Akademii Sztuk Pięknych w Warszawie (Dz.Urz. MWRiOP Nr 6-7, poz. 89). Z instytucji zebrania ogólnego profesorów na rzecz senatu w swym Statucie z dnia 28 I 1921 r. zrezygnował Uniwersytet Poznański (Dz.Urz. MWRiOP Nr 7, poz. 78). Zob.: J. Jędrzejewski, Instytucja zebrania ogólnego profesorów w państwowych szkołach akademickich II Rzeczypospolitej, "Zeszyty Naukowe Uniwersytetu Jagiellońskiego" 2010, t. 1312, z. 137, s. 166-168; K. Wojtczak, O ustroju szkół wyższych na przestrzeni lat 1920-1990, „Studia Prawa Publicznego" 2013, nr 3, s. 43-78.

${ }^{47}$ Wraz z wejściem w życie ustawy z dnia 15 III 1933 r. (tj. od dnia 1 X 1933 r.) od tego rozwiązania odstąpiono. Odtąd w państwowych szkołach akademickich zarówno 
i oświecenia publicznego do zatwierdzenia (192048). Ustanawiały także obowiązek dochowania warunków procedurę tę poprzedzających. Mianowicie pod rządami obu ustaw o szkołach akademickich wymagano od komisji, specjalnie powołanej przez radę wydziałową dla rozważenia kandydatur, opartej na referacie (1920), ankiecie (1933), dokonania oceny kandydata lub kandydatów. I choć postępowanie w sprawie prowadzącej do wyłonienia kandydatów na profesorów było pod rządami obu ustaw zbliżone, wyraźnie je mocniej formalizowała ustawa z $1933 \mathrm{r}$. i wydane na jej podstawie rozporządzenie wykonawcze z dnia 21 października 1933 r. $^{49}$

jedno-, jak i wielowydziałowych obligatoryjnie strukturą organizacyjna, określoną w statucie, objęto zebranie ogólne profesorów (ze zmienionym zakresem kompetencji), przy zachowaniu senatu jako drugiego organu obowiązkowego, stanowiącego naczelną władzę kolegialną szkoły, w zakresie niepowierzonym innym władzom akademickim (Dz.U. Nr 29, poz. 247). Zatwierdzanie wniosków rad wydziałowych o powołaniu profesorów zwyczajnych, nadzwyczajnych, honorowych nie leżało już w gestii zebrania ogólnego profesorów, lecz senatu. Możliwe były jednak wyjątki od tej zasady, zob. np. Rozporządzenie Ministra Wyznań Religijnych i Oświecenia Publicznego z dnia 23 VI 1934 r. w sprawie ustalenia pierwszego składu zebrania ogólnego profesorów i grona nauczycieli akademickich Akademii Sztuk Pięknych w Warszawie (Dz.Urz. MWRiOP Nr 6-7, poz. 89), które powierzyło zebraniu ogólnemu profesorów poza kompetencjami przypisanymi temu organowi ustawą z 1933 r. także funkcje senatu i rady wydziałowej.

Z kolei prywatne szkoły akademickie przyjęły tu różne rozwiązania. Przykładowo, Statut Szkoły Głównej Handlowej w Warszawie, zatwierdzony dnia 11 II 1935 r. (Dz.Urz. MWRiOP Nr 6, poz. 63) wśród władz akademickich nie przewidywał zebrania ogólnego profesorów, naczelną władzą kolegialną szkoły był senat z prawem mianowania profesorów zwyczajnych, nadzwyczajnych i honorowych po uprzednim zatwierdzeniu ich przez ministra wyznań religijnych i oświecenia publicznego. Natomiast Statut Wolnej Wszechnicy Polskiej w Warszawie, zatwierdzony dnia 11 X 1935 r. (Dz.Urz. MWRiOP Nr 12, poz. 210), przewidywał zarówno zebranie ogólne profesorów, jak i senat, ten ostatni organ szkoły uznając za jego naczelną władzę kolegialną z prawem uchwalania wniosków w sprawie mianowania profesorów. Z kolei statutem Akademii Handlu Zagranicznego we Lwowie, zatwierdzonym dnia 26 XI 1938 r. (Dz.Urz. MWRiOP Nr 13, poz. 391), powoływanie profesorów za zgodą ministra powierzono radzie profesorów, senatu nie utworzono. Takie rozwiązanie przyjęto również statutem Akademii Handlowej w Krakowie, zatwierdzonym dnia 21 III 1939 r. (Dz.Urz. MWRiOP Nr 3, poz. 91). Inne rozwiązanie przyjęto natomiast statutem Katolickiego Uniwersytetu Lubelskiego, zatwierdzonym dnia 10 III 1939 r. (Dz.Urz. MWRiOP Nr 3, poz. 90). Wprawdzie poza senatem statut przewidywał także ogólne zebranie profesorów (z prawem wypowiadania się jedynie w sprawie statutu i jego zmiany), jednak powoływanie profesorów należało do senatu za zgodą Wielkiego Kanclerza.

${ }^{48}$ Zob. art. 42 ust. 1 Ustawy z dnia 13 VII 1920 r. o szkołach akademickich.

${ }^{49}$ Rozporządzenie Ministra Wyznań Religijnych i Oświecenia Publicznego z dnia 27 X 1933 r. w sprawie wykonania postanowień art. 33 ustawy z dnia 15 III 1933 r. o szkołach akademickich (Dz.Urz. MWRiOP Nr 16, poz. 210). 
Na mocy ustawy z 1920 r. dla wytypowania kandydatów najodpowiedniejszych wyłoniona przez radę wydziałową komisja zwracała się do wszystkich profesorów (honorowych, zwyczajnych i nadzwyczajnych) we wszystkich szkołach akademickich polskich, wykładających przedmiot, o którego katedrę chodziło, z żądaniem nadesłania uzasadnionej opinii, jakich kandydatów należy uznać za najodpowiedniejszych. Po upływie dwóch miesięcy od daty rozesłania wezwań komisja mogła przystapić do rozpatrzenia nadesłanych wniosków, przygotować referat i przedstawić go radzie wydziałowej. Na tej podstawie rada wydziału wybierała kandydata ${ }^{50}$ i przedstawiała go zebraniu ogólnemu bądź senatowi do przyjęcia i zaprezentowania ministrowi wyznań religijnych i oświecenia publicznego do zatwierdzenia. Gdyby z jakiegokolwiek powodu minister nie uznał wniosku rady wydziałowej za trafny, rada mogła ponawiać wniosek aż do osiągnięcia porozumienia. W każdym razie wbrew woli rady i bez jej wniosku nie mogło nastąić mianowanie. Od tego trybu postępowania rada mogła odstąpić jedynie wtedy, gdy proponowany przez nią kandydat do mianowania był profesorem zwyczajnym, nadzwyczajnym lub honorowym w jednej z państwowych szkół akademickich polskich.

Tymczasem ustawa z $1933 \mathrm{r}$. i wydane na jej podstawie rozporządzenie wykonawcze tę swobodę procedury zawęziły. $W$ razie opróżnienia katedry (katedrą mógł nadal kierować profesor ${ }^{51}$ ) lub utworzenia nowej katedry wyznaczały dziekanowi, radzie wydziałowej oraz powołanej przez nią komisji specjalnej wyraźnie określone zadania i terminy

${ }^{50}$ Zgodnie z art. 42 ust. 3 ustawy z 1920 r. wniosek miał zawierać nazwiska dwóch kandydatów, jeżeli uchwała nie zapadła jednomyślnie, a mniejszość żądała, aby jej kandydat został we wniosku uwzględniony. Do wniosku należało dołączyć prace naukowe kandydata (lub też - od 1924 r. - reprodukcje utworów sztuki, gdy szło o mianowanie artysty), dokumenty osobiste, życiorys, referat komisji, a także wszystkie nadesłane referaty profesorów wezwanych przez komisję. Zmianę treści tego przepisu uzasadniało nadanie w 1924 r. Akademii Sztuk Pięknych w Krakowie statusu szkoły akademickiej. Zob. Ustawa z dnia 16 VII 1924 r. o zmianie niektórych przepisów ustawy z dnia 13 VII 1920 r. o szkołach akademickich (Dz.U. Nr 2, poz. 10).

${ }^{51}$ Kierownikiem zakładu był profesor, z którego katedrą zakład był związany. Kierownikiem zakładu niezwiązanego z żadną katedrą albo obejmującego swym zakresem kilka katedr był ten profesor, któremu kierownictwo powierzył minister wyznań religijnych i oświecenia publicznego na wniosek rady wydziałowej - w odniesieniu do zakładu należącego do jednego wydziału, na wniosek senatu - we wszystkich innych przypadkach. Od połowy 1937 r. pełnienie obowiązków kierownika zakładu mogło być powierzone także zastępcy profesora lub docentowi, zob. art. 1 pkt 12 Ustawy z dnia 2 VII 1937 r. o zmianie ustawy z dnia 15 III 1933 r. o szkołach akademickich (Dz.U. Nr 52, poz. 406). 
ich wykonania. Na podstawie uchwały rady wydziałowej w sprawie zwrócenia się do wszystkich profesorów, wykładających dany przedmiot (lub przedmiot pokrewny) we wszystkich szkołach akademickich z żądaniem wskazania kandydatów - dziekan zwracał się do każdego z profesorów nadzwyczajnych i zwyczajnych (tu z wyłączeniem profesorów honorowych) tych szkół ${ }^{52}$, z żądaniem nadesłania opinii, jakich kandydatów uważa dany profesor za najodpowiedniejszych. Zapytanie dziekana nie mogło zawierać nazwisk kandydatów już zgłoszonych ani sugerowanych do zgłoszenia. Udzielone odpowiedzi, wyznaczone dwutygodniowym terminem, w szczególnych warunkach terminem jednomiesięcznym, miały zawierać nazwiska kandydatów, których zapytany profesor uważa za najodpowiedniejszych, i to w porządku takim (wyczerpująco umotywowanym), w jakim jego zdaniem na to stanowisko się nadają. Umotywowania wymagały także odpowiedzi odmowne zapytanych profesorów (w razie niemożności wskazania żadnego kandydata). Bezzwłocznie po otrzymaniu odpowiedzi (bez względu na ich liczbę) dziekan w terminie miesiąca od rozesłania zapytań przedstawiał radzie wydziału wniosek o powołanie specjalnej komisji ${ }^{53}$ do obsadzenia danej katedry. Komisja, której dziekan przewodniczył $\mathrm{z}$ urzędu, miała w swym wniosku wskazać osobę, której kandydaturę uznała za najbardziej odpowiednia, ale mogła też wskazać dwóch lub więcej kandydatów, a także wystąpić z wnioskiem o odstąpienie w tym czasie od obsady katedry. Poszczególni członkowie komisji niegodzący się z uchwałami komisji mieli natomiast prawo przedstawienia radzie wydziału własnych wniosków. Podstawę do dyskusji podczas obrad rady wydziału stanowiły: protokół komisji oraz referaty członków komisji i wnioski. Kandydatem rady wydziału w głosowaniu jawnym (w głosowaniu tajnym tylko na żądanie 1/4 obecnych) był ten, który otrzymał więcej niż połowę głosów jej członków obecnych przy głosowaniu. Jeżeli żaden z kandydatów nie uzyskał wymaganej większości głosów, zarządzano drugie głosowanie. Jeśli zaś taka sytuacja powtarzała się

52 Przy czym dość szeroko określono tu oczekiwania w zakresie kwalifikacji naukowych kandydatów najodpowiedniejszych - jako także tych „wykładających w szerszym lub węższym zakresie dany przedmiot (bez względu na nazwę katedry przez nich zajmowanej i wydziału, do którego katedra ta należała), § 2 ust. 1 Rozporządzenia Ministra Wyznań Religijnych i Oświecenia Publicznego z dnia 27 X 1933 r.

${ }^{53}$ Komisję miało tworzyć od trzech do pięciu członków, będących profesorami, wykładających w tej samej uczelni dany przedmiot lub przedmioty pokrewne, wyjątkowo w skład komisji mogli wejść także zaproszeni profesorowie honorowi tej samej lub profesorowie innych uczelni ( $\$ 6$ rozporządzenia z dnia 27 X 1933 r.). 
także w drugim głosowaniu, rada wydziałowa mogła postąpić na jeden z dwóch sposobów: albo (1) przedstawić ministrowi wyznań religijnych i oświecenia publicznego wyniki głosowania przy założeniu, że jako jej kandydata uznaje każdego, kto otrzymał co najmniej 1/2 głosów oddanych, albo (2) podjać uchwałę o odroczeniu sprawy wraz z jej odesłaniem do tej samej lub innej komisji, gdy nikt $z$ kandydatów nie uzyskał $1 / 2$ głosów.

Bez względu na dokonany przez radę wydziałową wybór drogi postępowania i jej wyniki minister wyznań religijnych i oświecania publicznego mógł nie przedstawić do nominacji żadnego z zaproponowanych przez tę radę kandydatów, co zobowiązywało ją do ponownego przekazania sprawy powołanej przez nią komisji i sporządzenia ponownego referatu oraz nowego wniosku w terminie ustalonym przez tegoż ministra. $W$ razie ponownego nieuwzględnienia wniosku postępowanie to prowadzono nadal, a kandydaci poprzednio nieuwzględnieni przez ministra mogli być ponownie przedstawieni tylko po wykazaniu się nowym dorobkiem naukowym. Wniosek przedstawiony przez radę wydziałową ministrowi wyznań religijnych i oświecenia publicznego za pośrednictwem senatu wymagał jego opinii ${ }^{54}$.

Rozwiązania te dotyczyły szkół akademickich (państwowych i prywatnych), przewidzianych ustawą z 1933 r., w brzmieniu nadanym tekstem jednolitym w 1937 r. Przy czym zmieniona w tymże roku ustawa ${ }^{55}$ zarazem zobowiązała ministra wyznań religijnych i oświecenia publicznego do ustalenia, w drodze rozporządzenia, terminów zastosowania ustawy z 1933 r. do czterech spośród siedmiu prywatnych szkół akademickich: Akademii Handlu Zagranicznego we Lwowie (dawnej Wyższej Szkoły Handlu Zagranicznego we Lwowie $)^{56}$, Akademii Handlowej w Krakowie (dawnego Wyższego Studium Handlowego) ${ }^{57}$, Akademii

${ }^{54}$ Ustawa senatowi pozostawiała szczegółowe określenie sposobu przeprowadzenia ankiety, sposobu ustalenia składu specjalnej komisji i trybu jej postępowania oraz przedstawiania wniosków o mianowanie (art. 33 ust. 4).

${ }^{55}$ Ustawa z dnia 29 III 1937 r. o zmianie ustawy z dnia 15 III 1933 r. o szkołach akademickich.

${ }^{56}$ Zob. Rozporządzenie Ministra Wyznań Religijnych i Oświecenia Publicznego z dnia 13 VIII 1937 r. o ustaleniu terminu zastosowania przepisów ustawy z dnia 15 III 1933 r. o szkołach akademickich do Wyższej Szkoły Handlu Zagranicznego we Lwowie (Dz.Urz. MWRiOP Nr 11, poz. 334) na dzień 1 X 1937 r.

${ }^{57}$ Zob. Rozporządzenie Ministra Wyznań Religijnych i Oświecenia Publicznego z dnia 24 V 1938 r. o ustaleniu terminu zastosowania przepisów ustawy z dnia 15 III 1933 r. o szkołach akademickich do Wyższego Studium Handlowego w Krakowie (Dz.Urz. MWRiOP Nr 6, poz. 155) na dzień 1 IX 1938 r. 
Handlowej w Poznaniu (dawnej Wyższej Szkoły Handlowej w Poznaniu) ${ }^{58}$ oraz Akademii Nauk Politycznych w Warszawie (dawnej Szkoły Nauk Politycznych w Warszawie $)^{59}$. I tę delegację minister zrealizował. Ale też, na mocy art. 2 ustawy z dnia 29 marca 1937 r., minister zobowiązany do jej wykonania nadto ustanowił, w drodze rozporządzenia ${ }^{60}$, komisje dla oceny kwalifikacji naukowych czynnych profesorów wykładających w każdej z powyższych szkół oraz tryb działania tych komisji i warunki orzekania przez nie o każdej osobie wykładającej i profesorze wymienionych szkół ${ }^{61}$. Zastrzegał jednocześnie, że uchwały komisji mają dla ministra wyznań religijnych i oświecenia publicznego jedynie charakter opinii w procesie zatwierdzania wykładających i profesorów.

\section{Tytuły profesora w pierwszych latach Polski Ludowej}

Pierwsze lata Polski Ludowej w prawnym uregulowaniu szkół akademickich nie przyniosły większych zmian. Nadal obowiązywały: ustawa z 1933 r. w brzmieniu jej nadanym w roku $1937^{62}$ oraz wydane na jej podstawie przepisy wykonawcze. Stan faktyczny polskiego szkolnictwa akademickiego w roku 1945 nie był jednak porównywalny ze stanem sprzed 1939 r. Zmalała nie tylko liczba czynnych szkół akademickich, ale

${ }^{58}$ Zob. Rozporządzenie Ministra Wyznań Religijnych i Oświecenia Publicznego z dnia 25 X 1938 r. o ustaleniu terminu zastosowania przepisów ustawy z dnia 15 III 1933 r. o szkołach akademickich do Wyższej Szkoły Handlowej w Poznaniu (Dz.Urz. MWRiOP Nr 12, poz. 365) na dzień 10 XI 1938 r.

${ }^{59}$ Zob. Rozporządzenie Ministra Wyznań Religijnych i Oświecenia Publicznego z dnia 28 IV 1939 r. o ustaleniu terminu zastosowania przepisów ustawy z dnia 15 III 1933 r. o szkołach akademickich do Szkoły Nauk Politycznych w Warszawie (Dz.Urz. MWRiOP Nr 4, poz. 131) na dzień 1 IX 1939 r.

${ }^{60}$ Zob. Rozporządzenie Ministra Wyznań Religijnych i Oświecenia Publicznego z dnia 29 X 1937 r. o ustanowieniu komisji oceny kwalifikacji nauczycieli akademickich Akademii Handlu Zagranicznego we Lwowie, Wyższego Studium Handlowego w Krakowie, Wyższej Szkoły Handlowej w Poznaniu i Szkoły Nauk Politycznych w Warszawie (Dz.Urz. MWRiOP Nr 13, poz. 384).

${ }^{61}$ Spod ocen kwalifikacyjnych (osobistych i naukowych) wyłączono: wykładających i profesorów szkół akademickich, członków Polskiej Akademii Umiejętności, Akademii Nauk Technicznych, Towarzystwa Naukowego w Warszawie i Towarzystwa Naukowego we Lwowie oraz kierowników samodzielnych placówek naukowych, noszących wyraźnie charakter naukowo-badawczy ( $\$ 8$ rozporządzenia).

${ }^{62}$ Obwieszczenie Ministra Wyznań Religijnych i Oświecenia Publicznego z dnia 8 XI 1937 r. w sprawie ogłoszenia jednolitego tekstu ustawy z dnia 15 III 1933 r. o szkołach akademickich (Dz.U. 1938 Nr 1, poz. 6 ze zm.). 
również liczba profesorów zdolnych do prowadzenia pracy naukowej i dydaktycznej. Wprawdzie w 1945 r. otwarto kilka szkół wyższych ${ }^{63}$, jednak ówczesne szkoły akademickie z trudem godziły realizację swych zadań naukowych i dydaktycznych. Dysponowały nie tylko uboga infrastrukturą lokalową i warsztatowa, ale także nadal niewystarczającą kadrą kształcąca, nie wspominając już o bardzo niskich wynagrodzeniach profesorów i ich warunkach zamieszkania. I choć wielu profesorów uczelni pozostawionych poza nowo wytyczoną granicą wschodnią Polski zasiliło polskie szkoły akademickie, w tym szczególnie te nowo utworzone, zasób kadry profesorskiej kształtował się nadal na niskim poziomie. Nie bez uzasadnienia Prezydent Krajowej Rady Narodowej na wniosek ministra oświaty, złożony po wysłuchaniu opinii właściwej rady wydziałowej mógł, na mocy dekretu z dnia 16 listopada 1945 r. ${ }^{64}$, w ciągu dwóch lat od jego wejścia w życie: (1) mianować profesorów państwowych szkół akademickich spośród docentów lub profesorów szkół akademickich, w szczególnych przypadkach spośród niehabilitowanych pracowników naukowych, z pominięciem postępowania wymagającego rozpisania przez radę wydziałową ankiety dla wyłonienia właściwych kandydatów (art. 33 ustawy), jak i (2) przenosić profesorów państwowych szkół akademickich do katedr, innych szkół akademickich (państwowych), odpowiadających ich specjalności. Czy treść tego dekretu w zakresie mianowania profesorów mogła wśród rektorów budzić wątpliwości w stosowaniu Rozporządzenia Ministra Oświaty z dnia 27 października 1933 r. w sprawie wykonania postanowień art. 33 ustawy o szkołach akademickich, trudno jednoznacznie ustalić. Jedynie na podstawie wydanego w niecałe dwa lata później okólnika nr 18 z dnia 2 czerwca 1947 r. ${ }^{65}$ można założyć, że wątpliwości

${ }^{63}$ Zob. Dekret Polskiego Komitetu Wyzwolenia Narodowego z dnia 23 X 1944 r. o utworzeniu Uniwersytetu Marii Curie-Skłodowskiej w Lublinie (Dz.U. Nr 9, poz. 42); Dekret z dnia 24 V 1945 r. o utworzeniu Politechniki Śląskiej (Dz.U. Nr 21, poz. 118); Dekret z dnia 24 V 1945 r. o utworzeniu Uniwersytetu Lódzkiego); Dekret z dnia 24 V 1945 r. o utworzeniu Politechniki Łódzkiej (Dz.U. Nr 21, poz. 120); Dekret z dnia 24 VIII 1945 r. o utworzeniu Uniwersytetu Mikołaja Kopernika w Toruniu (Dz.U. Nr 34, poz. 208); Dekret z dnia 8 X 1945 r. o utworzeniu Akademii Lekarskiej w Gdańsku (Dz.U. Nr 44, poz. 253).

${ }^{64}$ Dekret z dnia 16 XI 1945 r. o zmianie przepisów dotyczących szkół akademickich i stosunku służbowego profesorów i pomocniczych sił naukowych tych szkół (Dz.U. Nr 56, poz. 313). Dekret ten uchylono dopiero 7 II 1952 r. Ustawą z dnia 15 XII 1951 r. o szkolnictwie wyższym i o pracownikach nauki.

${ }^{65}$ Okólnik nr 18 z dnia 2 VI 1947 r. o sposobie postępowania przy obsadzaniu katedr i zatwierdzaniu habilitacji w szkołach akademickich oraz o używaniu tytułu profesora lub docenta (Dz.Urz. Min. Oświaty Nr 9, poz. 141). 
takie powstały. Dokumentem tym podsekretarz stanu w ministerstwie oświaty, powołując się na niejednolitość postępowania rektorów przy przedkładaniu wniosków o nominacje profesorów, przypomniała o nadal obowiązującej treści § 19 rozporządzenia Ministra Oświaty z dnia 27 października 1933 r. Równocześnie „zwróciła uwagę, że używanie tytułu profesora, zastępcy profesora [...] może mieć miejsce nie wcześniej, jak od chwili otrzymania nominacji podpisanej przez Prezydenta Rzeczypospolitej [...]. Praktyka odmienna, będąca w wielu uczelniach w użyciu, jest niezgodna z obowiązującymi przepisami prawnymi".

Koniec października 1947 r. tej optyki postrzegania ówczesnej rzeczywistości wiele nie zmienił. W ślad za dekretem $z$ dnia 16 listopada 1945 r. dekret z dnia 28 października 1947 r. przyjął, że w okresie reorganizacji szkół wyższych, wyznaczonym okresem najbliższych pięciu lat ${ }^{66}$, profesorowie mogli być przez władze właściwe do mianowania zwalniani i przenoszeni z jednej szkoły do innej, do katedr odpowiadających ich specjalności (art. 113 ust. 1 pkt 2). Również w zakresie nominacji profesorskich przepisy dekretu były zbliżone do rozwiązań wcześniejszych. To, co dyktowało warunki nowe, wtedy uzasadniane potrzebą dostosowania prawnych rozwiązań do zasad budowy państwa komunistycznego, sprowadzało się do organów właściwych i procedury postępowania w zakresie nadawania tytułu naukowego profesora oraz prawa mianowania profesorów szkoły akademickiej.

Dekret z dnia 28 października 1947 r. zachował tytuły profesora zwyczajnego i nadzwyczajnego i, w ślad za rozwiązaniami ustawy z 1933 r., ciężar regulacji skierował na proces mianowania profesorów szkoły akademickiej. Profesorem szkoły akademickiej mogła być osoba, która wykazała się poważnym dorobkiem naukowym w danej dziedzinie wiedzy. Nominacja profesora nadzwyczajnego na profesora zwyczajnego była natomiast możliwa pod warunkiem wykazania przez kandydata, że jego dorobek naukowy powiększył się wydatnie w czasie profesury nadzwyczajnej.

Tym samym dekret stał się kolejnym instrumentem prawnym służącym zapewnieniu ówczesnym szkołom akademickim kadry naukowej,

${ }^{66} \mathrm{Na}$ mocy dekretu Rada Ministrów w drodze rozporządzenia, na wniosek ministra oświaty, przedstawiony za zgodą Rady Głównej do Spraw Nauki i Szkolnictwa Wyższego, miała ustalić, które z ówcześnie istniejących państwowych szkół wyższych miały zachować osobowość prawną, przy równoczesnym postanowieniu, że majątek tych szkół, które osobowości prawnej nie zachowają, przechodził na rzecz skarbu państwa (art. 111 ust. 1 i 3 ). 
i to profesorskiej, tak potrzebnej dla obsady poszczególnych katedr. Drogę do tego celu torowało: (1) nadawanie profesorowi nadzwyczajnemu tytułu profesora zwyczajnego oraz (2) mianowanie na stanowiska profesorów (nadzwyczajnych i zwyczajnych). O tym, że nie był to, wbrew pozorom, proces mało znaczący, świadczy także wydane niecały rok później zarządzenie Ministra Oświaty z dnia 3 lipca 1948 r. ${ }^{67}$ zapowiadające wprost, iż "[w] wypadku opróżnienia katedry prawo habilitowania ulega zawieszeniu tak długo, dokąd katedra nie zostanie obsadzona przez profesora zwyczajnego lub nadzwyczajnego".

Profesora zwyczajnego mianował Prezydent Rzeczypospolitej. Profesora nadzwyczajnego do nominacji przedstawiał minister oświaty za zgodą Rady Głównej do Spraw Nauki i Szkolnictwa Wyższego ${ }^{68}$ (co było nowym rozwiązaniem), na wniosek lub po wysłuchaniu opinii organów zainteresowanej szkoły (art. 68). Tym samym wobec mianowania profesorów (zwyczajnych, nadzwyczajnych i tytularnych) dekret przyjął różne rozwiązania zarówno w ujęciu materialno-, jak i formalnoprawnym. Profesorem szkoły akademickiej mogła być osoba, która wykazała się poważnym dorobkiem naukowym $w$ danej dziedzinie wiedzy, przy czym habilitacja nie była tu warunkiem koniecznym do mianowania w szkole akademickiej na jedno z tych stanowisk. Profesorem honorowym mógł być mianowany (jedynie w zakresie objętym dekretem nominacyjnym) wybitny uczony, zwłaszcza z grona ustępujących z katedr ${ }^{69}$. Profesorów z obu wskazanych grup mianował Prezydent Rzeczypospolitej na wniosek ministra oświaty - w odniesieniu do profesorów (zwyczajnych, nadzwyczajnych i tytularnych) spośród kandydatów przedstawionych przez Radę Główną, po wysłuchaniu opinii organów zainteresowanej szkoły akademickiej lub z jej inicjatywy (co było rozwiązaniem nowym), w odniesieniu zaś do profesorów honorowych za zgodą Rady Głównej z inicjatywy senatu szkoły akademickiej.

Tylko w odniesieniu do mianowania profesorów zwyczajnych, nadzwyczajnych i tytularnych szkół akademickich dekret, w ślad za rozwiązaniami z lat wcześniejszych, wymagał przeprowadzenia, tu już przez Radę Główną, postępowania kwalifikacyjnego, w drodze ankiety,

${ }^{67}$ Zarządzenie Ministra Oświaty z dnia 3 VII 1948 r. w sprawie tymczasowego nadania prawa habilitowania państwowym szkołom akademickim (Dz.Urz. Min. Oświaty Nr 9, poz. 146).

${ }^{68}$ Dalej „Rada Główna”.

${ }^{69}$ Profesorowi ustępującemu z katedry mógł minister oświaty przyznać prawo nauczania oraz prawo do korzystania z zakładów szkoły (art. 70 dekretu). 
służącego wytypowaniu najodpowiedniejszych kandydatów. Rada Główna mogła to uczynić w dwojaki sposób: albo (1) przeprowadzić ankietę przez wezwanie profesorów zwyczajnych i nadzwyczajnych szkół akademickich oraz kierowników samodzielnych placówek naukowo-badawczych, jak również innych wybitnych specjalistów, w których zakres badań wchodziła dana gałąź nauki, do nadesłania w określonym terminie umotywowanej opinii, jakich kandydatów należy uznać za najodpowiedniejszych, albo (2) publicznie ogłosić wezwanie do zgłaszania kandydatur. Pozyskane w ten sposób przez Radę Główną opinie, uznane przez nią za celowe, ta przedstawiała ocenie jej sekcji właściwej. Ani w sytuacji pierwszej, ani w sytuacji drugiej Rada Główna nie była związana otrzymanymi wynikami (ankiety, oceną sekcji). Brak odpowiedzi na ankietę także nie stanowił przeszkody do dalszego procedowania kwalifikacyjnego.

Oczywiście, procedury te mogły, lecz nie musiały, prowadzić do rozwiązania problemów kadrowych poszczególnych katedr. Nie bez uzasadnienia też dekret w sytuacjach przejściowych trudności w obsadzie katedry, jak i wtedy, gdy nie było możliwe powierzenie docentowi etatowemu prowadzenia zajęć związanych z katedra, pozwalał dla pełnienia tych funkcji powołać na czas określony, w drodze umowy, profesora kontraktowego spośród wybitnych specjalistów. Umowę tę $z$ kandydatem, zakwalifikowanym przez Radę Główną na wniosek lub po wysłuchaniu opinii organów szkoły, zawierał minister oświaty bez potrzeby przeprowadzenia postępowania kwalifikacyjnego. Przy zachowaniu tego trybu postępowania w braku kandydatów na profesorów kontraktowych przejściowe prowadzenie zajęć związanych z daną katedrą można było powierzyć zastępcy profesora, w drodze umowy na okres nie dłuższy niż trzy lata.

Bardziej liberalne rozwiązanie przyjął dekret w odniesieniu do nominacji w szkołach wyższych zawodowych. Profesorowi takiej szkoły, który wykazał się poważnym dorobkiem naukowym, Prezydent Rzeczypospolitej Polskiej mógł nadać tytuł profesora zwyczajnego na wniosek ministra oświaty, złożony za zgodą Rady Głównej (art. 58). Natomiast minister oświaty mianował profesorów i zastępców profesorów spośród wybitnych specjalistów, zakwalifikowanych przez Radę Główną. Z końcem grudnia 1949 r. ${ }^{70}$ ustawodawca rozwiązania te uczynił mniej wymagającymi. Przy mianowaniu na etaty państwowe

${ }^{70}$ Ustawa z dnia 30 XII 1949 r. o etatach państwowych w szkołach wyższych niepaństwowych (Dz.U. Nr 65, poz. 529). 
profesorów zajmujących już katedry w szkołach wyższych zawodowych niepaństwowych wprawdzie odsyłał do odpowiedniego stosowania postanowień dekretu z 1947 r., zarazem wyłączył jego stosowanie w zakresie mianowania (1) profesorów szkół wyższych zawodowych w ich kwalifikowaniu przez Radę Główną, a (2) profesorów szkół akademickich od przedstawienia ich kandydatów przez tę Radę.

\section{Tytuły profesora w okresie Polskiej Rzeczypospolitej Ludowej}

Od nazwy Państwo Polskie, przyjętej ustawą konstytucyjną w 1935 r., odstąpiono w roku 1952 na mocy Konstytucji uchwalonej przez Sejm Ustawodawczy w dniu 22 lipca $^{71}$. Wprawdzie niecałe sześć miesięcy wcześniej weszła w życie Ustawa z dnia 15 grudnia 1951 r. o szkolnictwie wyższym i o pracownikach nauki, jednak gros jej przepisów, w tym tych dotyczących nadawania tytułów profesora, obowiązywało bez większych zmian w okresie Polskiej Rzeczypospolitej Ludowej.

Ustawa z 1951 r. diametralnie zmieniła dotychczasową rzeczywistość (prawną i faktyczną). Najbardziej wyraźnie też odzwierciedlała nasilające się od końca lat czterdziestych ubiegłego stulecia dążenia podporządkowania szkolnictwa wyższego i jej kadry, w tym profesorskiej, sowieckiej ideologii. Ustawą tą objęto nie tylko nadawanie niższych i wyższych stopni naukowych na wzór rozwiązań radzieckich, ale także odpowiednio do nich prawo nadawania tytułów profesora oraz zachowanie tytułów dotychczasowych (dotychczasowi profesorowie zwyczajni i nadzwyczajni zachowywali przyznany im tytuł profesora, przy czym profesorowie zwyczajni uzyskiwali zarazem z mocy ustawy stopień naukowy doktora nauk, natomiast profesorowie nadzwyczajni mogli ten stopień naukowy uzyskać bez uprzedniego nabycia stopnia naukowego kandydata nauk).

Podobnie jak w latach wcześniejszych, profesor (a także każdy inny pracownik nauki) mógł być nadal z urzędu przenoszony do innej szkoły wyższej lub instytutu naukowego, w odróżnieniu jednak od tych rozwiązań (z lat 1945 i 1947) mógł być także przeniesiony na swój wniosek.

${ }^{71}$ Konstytucja Polskiej Rzeczypospolitej Ludowej uchwalona przez Sejm Ustawodawczy w dniu 22 VII 1952 r. 
Dopiero rok 1956 przyniósł dalszą zmianę tego stanu rzeczy ${ }^{72}$. Odtąd prawodawca wymagał tu ponadto opinii organów zarówno tej szkoły, w której pracownik był dotychczas zatrudniony, jak i tej, do której miał być przeniesiony.

Począwszy od dnia wejścia w życie ustawy z 1951 r., przyznawanie tytułów profesora zwyczajnego i nadzwyczajnego powierzono Centralnej Komisji Kwalifikacyjnej dla Pracowników Naukowych (CKK), co było rozwiązaniem nowym, podległej Prezesowi Rady Ministrów. CKK miała brać pod uwagę kwalifikacje: naukowe (poważny dorobek naukowy) i moralne kandydata oraz wyniki jego działalności naukowej. Zarazem, stosownie do wprowadzonych stopni naukowych, ustawa przyznanie tytułu naukowego profesora zwyczajnego rezerwowała dla osób posiadających wyższy stopień naukowy (doktora nauk), a tytułu profesora nadzwyczajnego - dla osób posiadających niższy stopień naukowy (kandydata nauk). W szczególnych przypadkach CKK mogła przyznać tytuł naukowy (przewidziany dla samodzielnego pracownika nauki) osobie nieposiadającej odpowiedniego stopnia naukowego. Stawiane w tym zakresie wymagania szczegółowo określono dość późno, bo dopiero w ostatnim kwartale 1953 r., uchwałą nr 4 CKK z dnia 3 października ${ }^{73}$ oraz wytycznymi przewodniczącego tej Komisji z dnia 5 października ${ }^{74}$. W istocie wykonywanie ustawy z $1951 \mathrm{r}$. bez aktów ustanowionych przez CKK nie było po jej wejściu w życie (7 lutego 1952 r.) możliwe. Trudności sprawiało także postanowienie art. 71 ust. 3 ustawy nakładające na CKK obowiązek zdecydowania o przyznaniu do dnia 31 grudnia 1952 r. odpowiednich tytułów naukowych innym dotychczasowym samodzielnym pracownikom nauki. Kłopot w tym, że do tego terminu pracownicy ci mogli zachować swoje dotychczasowe stanowiska. Rozwiązanie tego problemu przyniósł dzień wigilijny roku

72 Artykuł 1 pkt 43 Ustawy z dnia 10 IX 1956 r. o zmianie ustawy o szkolnictwie wyższym i o pracownikach nauki (Dz.U. Nr 41, poz. 185).

73 Obwieszczenie Przewodniczącego Centralnej Komisji Kwalifikacyjnej dla Pracowników Nauki z dnia 6 X 1953 r. dotyczące ogłoszenia uchwały nr 4 Centralnej Komisji Kwalifikacyjnej dla Pracowników Nauki z dnia 3 X 1953 r. w sprawie zasad przyznawania tytułu naukowego profesora nadzwyczajnego i zwyczajnego (M.P. Nr 99, poz. 1369).

${ }^{74}$ Obwieszczenie Przewodniczącego Centralnej Komisji Kwalifikacyjnej dla Pracowników Nauki z dnia 6 X 1953 r. dotyczące ogłoszenia wytycznych Prezydium Centralnej Komisji Kwalifikacyjnej dla Pracowników Nauki z dnia 5 X 1953 r. w sprawie składania i rozpatrywania wniosków o przyznanie tytułu naukowego profesora nadzwyczajnego i zwyczajnego (M.P. Nr 99, poz. 1370). 
1952. W tym dniu bowiem dekretem z dnia 24 grudnia 1952 r. ${ }^{75}$ wyrazy "do dnia 31 grudnia 1952 r." zastąpiono wyrazami "w terminie, który określi Prezydium Rządu". Dekret ten wszedł w życie z dniem 31 grudnia 1952 r. Terminu tego Prezydium Rządu nie określiło. Dopiero z dniem ogłoszenia Uchwały nr 4 przewodniczącego CKK z dnia 3 października 1953 r. Centralnej Komisji powierzono rozpatrzenie, na wniosek właściwego ministra lub prezydium PAN, sprawy dotyczącej przyznania tytułu naukowego profesora zwyczajnego osobom, w stosunku do których Rada Główna podjęła przed dniem wejścia w życie ustawy z dnia 15 grudnia $1951 \mathrm{r}$. uchwałę o wystąpieniu $\mathrm{z}$ wnioskiem o nominację na stanowisko profesora zwyczajnego (tu bez wymogu uchwały senatu w szkole wyższej lub rady naukowej w instytucie naukowo-badawczym) oraz utrzymano w mocy ust. 8 Uchwały nr 2 CKK z dnia 29 kwietnia $1953 \mathrm{r}^{76}$ ustalającej zasady przyznawania tytułu naukowego profesora nadzwyczajnego w przypadkach uzasadnionych wybitnym dorobkiem naukowym ${ }^{77}$ (tu z zachowaniem podjęcia przez senat, radę naukowa, stosownej uchwały ${ }^{78}$ ).

Ustawa wraz z ogłoszonymi przez CKK uchwałą i wytycznymi prezydium CKK wskazywały: (1) podmiot uprawniony do podjęcia postępowania kwalifikacyjnego w sprawie przyznania tytułu naukowego profesora (nadzwyczajnego lub zwyczajnego) i tryb jej działania, (2) warunki stawiane przed kandydatami do tytułu naukowego profesora oraz (3) warunki i przebieg postępowania kwalifikacyjnego.

W kwestii pierwszej, postępowanie kwalifikacyjne leżało w gestii CKK, działającej na wniosek właściwego ministra (sprawującego nadzór

${ }^{75}$ Dekret z dnia 24 XII 1952 r. o zmianie terminu przyznawania tytułów naukowych dotychczasowym samodzielnym pracownikom nauk (Dz.U. Nr 53, poz. 348).

${ }^{76}$ Uchwała nr 2 Centralnej Komisji Kwalifikacyjnej dla Pracowników Nauki z dnia 29 IV 1953 r. w sprawie zasad przyznawania tytułu naukowego docenta, stanowiąca załącznik do Obwieszczenia Przewodniczącego Centralnej Komisji Kwalifikacyjnej dla Pracowników Nauki z dnia 27 VI 1953 r. (M.P. Nr A-66, poz. 808).

$77 \mathrm{Tu}$ awans naukowy (przyznanie tytułu naukowego profesora nadzwyczajnego) mógł dotyczyć osób, które posiadały tytuł doktora (starego typu), w swym dorobku naukowym mają pracę naukową odpowiadającą wymaganiom pracy kandydackiej, wykonaną w okresie nie dłuższym niż trzy lata przed datą wystąpienia $\mathrm{z}$ wnioskiem o nadanie tytułu naukowego docenta, tj. przed 30 VI 1954 r., i odpowiadają pozostałym kwalifikacjom wymaganymi dla uzyskania tego tytułu naukowego (docenta).

${ }^{78}$ Dla ważności uchwały wymagano jej podjęcia większością głosów w głosowaniu tajnym w składzie senatu poszerzonym o zaproszonych przez rektora samodzielnych pracowników nauki wydziału w szkole wyższej (rady naukowej w instytucie naukowym) oraz zatwierdzeniu przez rektora szkoły wyższej (dyrektora instytutu naukowego). 
nad szkołą wyższą) lub prezydium $\mathrm{PAN}^{79}$. Dla ważności wniosku podejmowanego w szkole wyższej wymagano uchwały senatu podjętej w składzie rozszerzonym o zaproszonych przez rektora samodzielnych pracowników nauki właściwego wydziału (z prawem ich udziału w głosowaniu), a w przypadku jednostek naukowych PAN uchwały rady naukowej w instytucie naukowo-badawczym - w obu sytuacjach podjętej, w głosowaniu tajnym, większością głosów. Dla podjęcia przez senat (radę naukową w instytucie naukowo-badawczym PAN) uchwały rektor (dyrektor instytutu) występował o sporządzenie pisemnej opinii przez dwóch referentów wyznaczonych spośród profesorów zwyczajnych lub nadzwyczajnych, reprezentujących daną specjalność lub specjalności pokrewne. Opinia miała zawierać ocenę działalności i dorobku naukowego kandydata, ze szczególnym uwzględnieniem okresu po uzyskaniu przez niego tytułu naukowego posiadanego w chwili występowania $\mathrm{z}$ wnioskiem ${ }^{80}$. Przy czym w odniesieniu do PAN tryb przeprowadzania oceny działalności i dorobku kandydata ustalało jej prezydium.

W kwestii drugiej, zgodnie z uchwałą nr 4 CKK, wymagania w tym zakresie nieco różniły się stosownie do tego, o nadanie jakiego tytułu

${ }^{79}$ Zob. § 9 Uchwały nr 339 Rady Ministrów z dnia 26 IV 1952 r. w sprawie regulaminu Centralnej Komisji Kwalifikacyjnej dla Pracowników Nauki (M.P. Nr A-42, poz. 601) oraz § 7 Uchwały nr 166 Rady Ministrów z dnia 23 V 1960 r. w sprawie regulaminu Komisji Kwalifikacyjnej Pracowników Nauki (M.P. Nr 45, poz. 217).

${ }^{80}$ Właściwy minister lub prezydium PAN mogli z wnioskiem o przyznanie tytułu naukowego profesora wystąpić, jeżeli poza pisemnymi opiniami dwóch referentów do niego załączono ponadto: dokładny życiorys kandydata ze szczególnym uwzględnieniem jego działalności naukowej w okresie po uzyskaniu tytułu naukowego posiadanego $\mathrm{w}$ chwili występowania $\mathrm{z}$ wnioskiem; wypełnioną ankietę dla ubiegającego się o tytu naukowy według wzoru ustalonego przez CKK; wykaz prac naukowych; po jednym egzemplarzu prac naukowych, uznanych przez kandydata za szczególnie ważne dla decyzji CKK, a pochodzących z okresu po uzyskaniu przez niego posiadanego w chwili występowania $z$ wnioskiem tytułu naukowego. Biuro CKK mogło jednak kandydata zobowiązać do dostarczenia także innych egzemplarzy jego prac naukowych bądź do wskazania, gdzie prace te mogą być dostępne; dowód posiadania tytułu naukowego docenta i stopnia naukowego kandydata nauk lub doktora nauk - w przypadku ubiegania się o tytuł naukowy profesora nadzwyczajnego, w przypadku wniosku o przyznanie tytułu naukowego profesora zwyczajnego - dowód posiadania tytułu naukowego profesora nadzwyczajnego i stopnia naukowego doktora nauk; odpis protokołu. Jedynie w odniesieniu do szkół wyższych wymagano załączenia do wniosku również odpisu protokołu $\mathrm{z}$ posiedzenia senatu zawierającego szczegółowo uzasadnioną uchwałę w przedmiocie wniosku o przyznanie tytułu naukowego profesora nadzwyczajnego i zwyczajnego oraz dowody uzyskania przez kandydata nagród państwowych. We wszystkich natomiast przypadkach CKK mogła także żądać innych danych i dokumentów, włącznie z udzieleniem wyjaśnień. 
naukowego profesora chodziło. $\mathrm{W}$ istocie uchwała CKK doprecyzowywała postanowienia ustawy w tym zakresie. Zgodnie z nią zasadniczym warunkiem przyznania tytułu naukowego profesora nadzwyczajnego było posiadanie stopnia naukowego kandydata nauk (niższy stopień naukowy) bądź doktora nauk (wyższy stopień naukowy) oraz tytułu naukowego docenta. $Z$ kolei warunkiem przyznania tytułu naukowego profesora zwyczajnego było posiadanie stopnia naukowego doktora nauk i tytułu naukowego profesora nadzwyczajnego. Od kandydatów do tytułu naukowego profesora nadzwyczajnego, z zastrzeżeniem wypełnienia przez nich $\mathrm{w}$ okresie paroletnim nienagannie obowiązków samodzielnego pracownika nauki, wymagano wykazania się: (1) stale rozwijającą się działalnością naukowo-badawczą oraz stałym wzrostem poziomu dorobku naukowego, (2) twórczą inicjatywą w organizowaniu i systematycznym prowadzeniu pracy naukowo-badawczej oraz troską o wychowywanie młodej kadry naukowej, a także (3) w przypadku osób ubiegających się o tytuł naukowy profesora nadzwyczajnego pracujących w szkołach wyższych stałą i skuteczną troską o udoskonalenie metod i podnoszenie wyników nauczania. Od kandydatów do tytułu profesora zwyczajnego natomiast, tu już w ciągu swej kilkuletniej pracy na stanowisku profesora nadzwyczajnego wypełniającego nienagannie obowiązki pracownika nauki, wymagano wykazania się: (1) stale rosnącym dorobkiem naukowym, stanowiącym twórczy wkład do rozwoju danej dziedziny nauki, (2) poważnymi osiągnięciami w organizowaniu i kierowaniu pracą naukowo-badawczą w służbie gospodarki narodowej i kultury oraz poważnymi rezultatami w wychowywaniu kadry naukowej, (3) stałym wzrostem wyników w pracy nad kształceniem i wychowywaniem młodzieży - w przypadku osób ubiegających się o tytuł profesora zwyczajnego pracujących w szkołach wyższych ${ }^{81}$.

W kwestii trzeciej z kolei, CKK mogła przeprowadzać postępowanie kwalifikacyjne przy zachowaniu określonych warunków. Po jego wszczęciu rolą właściwej sekcji Komisji było dokonanie wstępnej oceny działalności kandydata i jego kwalifikacji naukowych i moralnych oraz przedłożenie prezydium CKK wniosku o przyznanie tytułu naukowego wraz z wynikami dokonanej oceny. Nimi nie były jednak związane ani

${ }^{81}$ Przy ocenie działalności i całokształtu dorobku naukowego kandydata do tytułu naukowego profesora nadzwyczajnego lub zwyczajnego należało brać pod uwagę, oprócz dorobku naukowego w formie publikacji, również i inne związane z działalnością kandydata twórcze osiągnięcia, które doprowadziły do uogólnień mających znaczenie dla rozwoju danej gałęzi nauki (ust. 5 uchwały nr 4 CKK). 
prezydium, ani ogólne zebranie CKK. Oceny prac naukowych dokonywano, w razie potrzeby, na podstawie opinii rzeczoznawców powoływanych przez przewodniczącego sekcji. Ich liczbę ustalało prezydium CKK i zatwierdzało na zebraniu ogólnym. O przyznaniu tytułu naukowego CKK zawiadamiała właściwego ministra oraz prezydium PAN, a samodzielnemu pracownikowi nauki wydawała zaświadczenie o przyznaniu mu tytułu naukowego ${ }^{82}$.

Począwszy od 1958 r., powrócono do niektórych rozwiązań sprzed 1951 r., co było wyrazem nawiązania do regulacji polskich w zakresie nominacji profesorskich, nieco zmodyfikowanych, a także w warunkach złagodzenia komunistycznych nacisków na naukę.

Wyrazem nowych rozwiązań było: (1) ustanowienie nowego organu uprawnionego do powoływania profesorów i trybu postępowania organów szkół wyższych w tym zakresie, (2) ograniczenie instytucji mianowania profesorów na rzecz ich powoływania (z pewnymi wyjątkami) i nadawania tytułów profesora, (3) określenie zmienionych warunków stawianych przed kandydatami do tytułu profesora. Z kolei wzorem rozwiązań wcześniejszych, poprzedzających rok 1951, (1) powrócono do ankiet przeprowadzanych przez radę wydziału wśród profesorów zwyczajnych i nadzwyczajnych dla wytypowania kandydatów najodpowiedniejszych z danego przedmiotu oraz (2) dopuszczono, w wyjątkowych przypadkach, do mianowania na stanowisko profesora (zwyczajnego lub nadzwyczajnego) osoby bez stopnia naukowego.

W myśl ustawy z 1958 r. na stanowisko profesora zwyczajnego lub profesora nadzwyczajnego powoływała Rada Państwa na wniosek ministra szkolnictwa wyższego przedstawiony przez Prezesa Rady Ministrów. Tylko osoba powołana na jedno z tych stanowisk uzyskiwała odpowiednio tytuł profesora i były to tytuły dożywotnie ${ }^{83}$. Zarazem

${ }^{82} \mathrm{Na}$ stanowisko profesora powoływał w szkole wyższej, instytucie naukowym lub innej placówce naukowej minister, któremu szkoła wyższa lub instytut (placówka naukowa) podlegała; od 1956 r. powołanie do pracy w szkole wyższej następowało na wniosek lub po wysłuchaniu opinii organów szkoły (art. 1 pkt 48 ustawy z dnia 10 IX 1956 r.), przy czym tryb powoływania do pracy pracowników nauki w jednostkach naukowych PAN określały odrębne przepisy.

${ }^{83}$ Pozbawienie tytułu profesora nadzwyczajnego lub profesora zwyczajnego mogło nastąpić: (1) z mocy prawa w razie skazania na karę pozbawienia praw publicznych lub obywatelskich praw honorowych, (2) w razie ukarania na karę więzienia za przestępstwa popełnione $\mathrm{z}$ chęci zysku lub z innych niskich pobudek bądź wymierzenia kary dyscyplinarnej wydalenia ze służby. O pozbawieniu tytułu naukowego orzekała Rada Państwa (art. 94 ustawy z 1958 r.). 
zastrzeżono, że na stanowisko profesora nadzwyczajnego mogła być powołana osoba, która na stanowisku docenta etatowego lub na takim stanowisku zajmowanym poza szkołą wyższą uzyskała poważne wyniki w pracy naukowej i dydaktycznej, zaś na stanowisko profesora zwyczajnego osoba, która na stanowisku profesora nadzwyczajnego wydatnie powiększyła swój dorobek naukowy i uzyskała poważne osiągnięcia w pracy dydaktycznej.

Prawo przedstawienia kandydatów na stanowiska profesorów (nadzwyczajnego i zwyczajnego) i do tytułu profesora przysługiwało wyłącznie radom wydziałów, którym przyznano uprawnienia do nadawania stopnia naukowego doktora. W przypadku rad wydziałów niemających takiego uprawnienia prawo w tym zakresie służyło Radzie Głównej Szkolnictwa Wyższego. W sytuacji pierwszej wniosek rady wydziału wymagał zgody senatu, poprzedzonej przeprowadzeniem przez radę wśród profesorów zwyczajnych i nadzwyczajnych danego przedmiotu, a $w$ razie potrzeby także przedmiotów pokrewnych, postępowania ankietowego. W sytuacji drugiej Rada Główna mogła ministrowi przedstawić wniosek o powołanie bądź o mianowanie na stanowisko profesora nadzwyczajnego i profesora zwyczajnego. Minister mógł z wnioskiem o mianowanie kandydata na stanowiska profesora wystąić także wyłącznie po zasięgnięciu opinii Rady Głównej.

W ten sposób ustawa oraz wydane na jej podstawie rozporządzenie wykonawcze $^{84}$, z zastrzeżeniem: „[j]eżeli w szkole wyższej na wydziale uprawnionym do nadawania stopnia naukowego doktora istnieją warunki do powołania profesora [...], a w szkole wyższej na wydziale uprawnienia tego nieposiadającego [...] zachodzi taka potrzeba", różnicowały tryb postępowania w sprawie wysuwania kandydatur na stanowiska profesorskie stosownie do tego, (1) o jaki tytuł profesora chodziło (nadzwyczajny, zwyczajny), (2) czy kandydatami do stanowisk (tytułów) profesorskich były osoby zajmujące czy niezajmujące na wydziale stanowiska samodzielnych pracowników nauki, (3) czy awans naukowy na stanowisko profesora zwyczajnego odnoszono do tego samego przedmiotu na tym samym wydziale uprawnionym do nadawania stopnia naukowego doktora czy na wydziale nieposiadającym uprawnienia $\mathrm{w}$ tym zakresie. $\mathrm{W}$ ten sposób rozdzielono instytucję powołania na

${ }^{84}$ Rozporządzenie Ministrów Szkolnictwa Wyższego, Zdrowia, Oświaty, Spraw Zagranicznych i Przewodniczącego Głównego Komitetu Kultury Fizycznej z dnia 22 IX 1959 r. w sprawie zasad i trybu wysuwania kandydatów na profesorów nadzwyczajnych i profesorów zwyczajnych w szkołach wyższych (Dz.U. Nr 58, poz. 350). 
stanowisko profesora od mianowania profesorów, zarazem przyjmując różne rozwiązania.

Postępowania ankietowego wymagano przy wysuwaniu kandydatury: (1) docenta etatowego na stanowisko profesora nadzwyczajnego zatrudnionego na tym samym wydziale uprawnionym do nadawania stopnia naukowego doktora, a także na wydziale nieuprawnionym do nadawania tego stopnia naukowego spośród osób niezajmujących na wydziale etatu samodzielnego pracownika nauki, (2) profesora nadzwyczajnego na stanowisko profesora zwyczajnego tego samego przedmiotu na tym samym wydziale, lecz nieuprawnionym do nadawania stopnia doktora. W sytuacji pierwszej postępowanie ankietowe miało na celu zebranie opinii, czy docent mógł być powołany na stanowisko profesora nadzwyczajnego. Pytaniem ankietowym mógł być objęty jeden kandydujący docent. W sytuacji drugiej natomiast pytanie ankietowe miało dać odpowiedź na pytanie, którego z kandydujących profesorów nadzwyczajnych należałoby mianować na stawisko profesora zwyczajnego.

Obowiązek przeprowadzenia postępowania ankietowego wiązał radę wydziału do podjęcia dwóch uchwał: pierwszej upoważniającej dziekana do przeprowadzenia postępowania ankietowego i drugiej w sprawie ukonstytuowania trzyosobowej komisji wybranej spośród samodzielnych pracowników nauki wraz z wyznaczeniem jej przewodniczącego do opracowania wyników postępowania ankietowego. W następstwie podjętych uchwał dziekan zwracał się do dziekanów odpowiednich wydziałów szkół wyższych i kierowników odpowiednich placówek naukowych, zatrudniających profesorów zwyczajnych i nadzwyczajnych danego lub pokrewnego przedmiotu, z prośbą o podanie, kogo ich zdaniem należy wziąć pod uwagę przy wysuwaniu przez radę wydziału kandydata na stanowisko profesora nadzwyczajnego lub profesora zwyczajnego. Ankietę tę dziekan mógł również skierować do profesorów zwyczajnych i nadzwyczajnych swego wydziału wykładających dany przedmiot lub przedmiot pokrewny. $Z$ zachowaniem jednomiesięcznego terminu odpowiedzi od dnia otrzymania ankiety, profesorowie mieli przesłać swoją opinię bezpośrednio lub za pośrednictwem swego dziekana lub kierownika placówki naukowej do dziekana wydziału przeprowadzającego postępowanie ankietowe; w opinii mogli wskazać więcej niż jednego kandydata, określając kolejność zgłaszanych nazwisk. Opinie miały charakter poufny. Po upływie wyznaczonego terminu i przekazaniu przez dziekana komisji odpowiedzi oraz sprawdzeniu przez nią warunków wymaganych prawem i przedstawieniu wyników 
ankiety na zwołanym przez dziekana posiedzeniu rady wydziału ta w głosowaniu tajnym dokonywała wyboru kandydata. Kandydatem rady została osoba, która otrzymała bezwzględną większość głosów samodzielnych pracowników nauki - członków rady, przy obecności co najmniej 2/3 uprawnionych do głosowania. Warunkiem formalnym wymaganym dla przyjęcia osoby wybranej przez radę była jej pisemna zgoda. W razie odmowy jej wyrażenia rada wydziału wybierała innego kandydata. Wybór przez radę osoby aspirującej do awansu naukowego nie zamykał postępowania. Dziekan wydziału przekazywał jego wyniki rektorowi szkoły wyższej dla zasięgnięcia opinii senatu. Dopiero po powzięciu przez senat uchwały w sprawie wyrażającej opinię na temat kandydata wysuniętego przez radę wydziału na stanowisko profesora nadzwyczajnego lub zwyczajnego rektor mógł przedstawić ministrowi sprawującemu zwierzchni nadzór nad szkołą wyższą wniosek rady wydziału wraz z opinią senatu.

Nieco inne rozwiązania przyjęto w odniesieniu do awansów naukowych profesorów nadzwyczajnych. Wprawdzie i tutaj nie bez znaczenia pozostawało to, czy wysuwanie kandydatury profesora nadzwyczajnego na stanowisko profesora zwyczajnego dotyczyło osoby zatrudnionej na wydziale posiadającym czy nieposiadającym uprawnienia do nadawania stopnia naukowego doktora, oraz czy dotyczyło to profesora zwyczajnego tego samego przedmiotu, jednak znaczenie tej delimitacji było wyraźniejsze. Nie wymagano tu postępowania ankietowego, które zastąpiono innym postępowaniem. W sytuacji pierwszej dziekan zwracał się z wnioskiem do rady wydziału, która po rozpatrzeniu sprawy miała wybrać spośród samodzielnych pracowników nauki trzyosobową komisję do opracowania i przedstawienia dziekanowi opinii, czy wskazany we wniosku profesor nadzwyczajny spełnia warunki ustawowe (dorobek naukowy wydatnie powiększony i poważne osiągnięcia w pracy dydaktycznej). Po uzyskaniu tej opinii komisji dziekan przesyłał ją dwom recenzentom danego lub pokrewnego przedmiotu zatrudnionym $w$ innej szkole wyższej lub placówce naukowej. Opinia komisji oraz recenzje stanowiły dla rady wydziałowej podstawę do podjęcia uchwały w sprawie wystąpienia $z$ wnioskiem o powołanie zatrudnionego na wydziale profesora nadzwyczajnego na stanowisko profesora zwyczajnego, o ile za wnioskiem wypowiedziała się bezwzględna większość członków rady wydziału uprawnionych do głosowania, przy obecności co najmniej 2/3 samodzielnych pracowników nauki - członków rady wydziału. Dziekan wydziału przekazywał wniosek rady rektorowi szkoły wyższej, ten zaś 
po zasięgnięciu opinii senatu wniosek wraz z opinią senatu przekazywał ministrowi sprawującemu nadzór nad szkołą wyższą.

Od zasady, że wysuwanie kandydatury docenta etatowego na stanowiska profesora nadzwyczajnego oraz profesora nadzwyczajnego na stanowisko profesora zwyczajnego leżało w gestii rady wydziału, przewidziano wyjątki. Minister mógł mianowicie zwrócić się do Rady Głównej o wysunięcie kandydata wydziału nieuprawnionego do nadawania stopnia doktora na stanowisko profesora nadzwyczajnego lub profesora zwyczajnego: (1) tego samego przedmiotu na tym samym wydziale, a także (2) spośród osób niezajmujących na wydziale etatów samodzielnych pracowników nauki. W tych przypadkach czynności przewidziane dla rady wydziału wykonywało prezydium Rady Głównej, a czynności przewidziane dla dziekana - sekretarz tej Rady. W sytuacji pierwszej rektor przedstawiał ministrowi sprawującemu nadzór nad szkołą wyższą sprawę wysunięcia kandydata do awansu naukowego, ten zaś (minister) pozostawiał Radzie Głównej rozstrzygnięcie sprawy i ewentualne wysunięcie kandydata w sprawie mianowania docenta etatowego na stanowisko profesora nadzwyczajnego lub profesora nadzwyczajnego na stanowisko profesora zwyczajnego. W sytuacji drugiej natomiast po podjęciu przez prezydium Rady Głównej uchwały w sprawie wysunięcia kandydatur na stanowisko profesora nadzwyczajnego lub zwyczajnego i przekazaniu przez sekretarza Rady Głównej uchwały wraz z materiałami ankietowymi i oceną komisji rektorowi szkoły wyższej w celu przedstawienia kandydatury senatowi do opinii, po jej otrzymaniu prezydium Rady Głównej podejmowało uchwałę wyrażającą wniosek o powołaniu na stanowisko profesora nadzwyczajnego lub zwyczajnego osoby wybranej przez Radę Główną.

Tę dość zawiłą procedurę postępowania przy występowaniu z wnioskiem w sprawie wysuwania kandydatur do awansów naukowych można usprawiedliwić jedynie przejściem od rozwiązań przyjętych w tym zakresie pod rządami ustawy z 1951 r. do rozwiązań nowych, objętych ustawą z 1958 r. ${ }^{85}$

${ }^{85}$ Zgodnie z art. 147 ustawy z dnia 5 XI 1958 r. osoby zatrudnione w szkole wyższej na stanowisku zastępcy profesora mogły do dnia 30 IX $1961 \mathrm{r}$. zachować to stanowisko, w tym wszystkie prawa i obowiązki przewidziane tą ustawą dla docentów etatowych w zakresie pełnienia funkcji w administracji dydaktyczno-naukowej szkoły wyższej; zastępca profesora pełniący funkcje kierownika katedry wchodził w skład rady wydziału. W innych sprawach miały do nich zastosowanie przepisy dotyczące wykładowców zatrudnionych na podstawie umowy o pracę, zob. § 3 Rozporządzenia Ministrów Szkolnictwa Wyższego, Zdrowia, Oświaty, Spraw Zagranicznych oraz Przewodniczącego 


\section{Podsumowanie}

Lata 1920-1990 to okres propozycji różnych rozwiązań prawnych wyznaczających pozycję ówczesnych profesorów. Nie był to okres łatwych przemian. W pierwszych latach Polski międzywojennej trzon kadry profesorskiej budowano z trudem. W roku 1919 potrzeb kadrowych ówczesnych szkół wyższych w pełni nie zaspokajały powroty polskich uczonych z uniwersytetów byłych państw zaborczych. Wraz z wprowadzeniem w 1920 r. pierwszej ustrojowej ustawy o szkołach akademickich nadawanie tytułów profesora nadzwyczajnego i profesora zwyczajnego także nie było częste i wystarczające. Lukę w zapewnieniu kadry profesorskiej częściej wypełniano instytucją mianowania ówczesnego nauczyciela akademickiego $\mathrm{w}$ zakresie danego przedmiotu realizowanego w ramach katedry określonej szkoły akademickiej, a także przez nadawanie innych tytułów profesora (honorowego, tytularnego, kontraktowego czy zastępcy profesora). W drugiej połowie lat Polski międzywojnia sytuacja ta wprawdzie uległa znacznej poprawie (wzrosła liczba szkół akademickich i jej kadry profesorskiej), jednak ten stan rzeczy przerwał w 1939 r. wybuch II wojny światowej.

W roku 1945 nie od razu przystąpiono do prac legislacyjnych nad prawnym uregulowaniem statusu szkół wyższych. Przez co najmniej dwa kolejne lata nadal obowiązywały przepisy z okresu drugiej połowy lat trzydziestych. Dalej działały szkoły akademickie, tyle że w warunkach lokalowych znacznie trudniejszych i słabo wyposażone, w liczbie pomniejszonej o polskie szkoły akademickie, które znalazły się poza terytorium Polski. Również stan kadry profesorskiej wyraźnie uległ obniżeniu. W trakcie II wojny światowej, a także po jej zakończeniu Polska utraciła wielu wybitnych profesorów poddanych eksterminacji. To, że przez blisko dwa kolejne lata (od 1945 r.) nadal obowiązywały przepisy dotyczące szkół wyższych z okresu drugiej połowy lat Polski międzywojennej, nie miało większego znaczenia. Zmiany wprowadzane do ustawy z 1933 r. o szkołach akademickich w roku 1945 zapowiadały bowiem kierunek przemian - przejście od burżuazyjnych szkół akademickich, za jakie wtedy szkoły te uważano, do szkół wyższych

Głównego Komitetu Kultury Fizycznej z dnia 25 VIII 1959 r. w sprawie określenia kwalifikacji wymaganych do zajmowania stanowisk wykładowcy i starszego wykładowcy w szkołach wyższych (Dz.U. Nr 58, poz. 349). Tylko ten zastępca profesora, który w powyższym terminie uzyskał stopień naukowy docenta, nabywał prawo do powołania go na stanowisko docenta etatowego w tej samej szkole wyższej. 
ideologicznie określonych nowym nurtem zmian. Tej ideologizacji stopniowo podporządkowywano również kolejne państwowe szkoły akademickie zarówno w tym czasie otwierane bądź przekształcane, jak i nowo tworzone.

Reforma z roku 1947 ten stan prawny i faktyczny ugruntowała. Wprawdzie szkoły wyższe zachowały status szkół akademickich, spośród nich działały jednak tylko te, które na mocy rozporządzenia Rady Ministrów mogły zachować osobowość prawną. Miało to wpływ także na dobór kadry profesorskiej. Tytułów naukowych (profesora zwyczajnego i profesora nadzwyczajnego) nie nadano wiele. Wzorem rozwiązań wcześniejszych główny ciężar skoncentrowano na budowaniu kadry profesorskiej z wykorzystaniem instytucji mianowania profesora danego przedmiotu (katedry lub wydziału określonej szkoły akademickiej).

Rok 1951 rzeczywistość tę zmienił. O wiele wyraźniej i mocniej zaznaczały się bowiem wpływy wzorców radzieckich. Do tytułu profesora nadzwyczajnego mógł aspirować kandydat nauk, profesora zwyczajnego - doktor nauk. Wprawdzie nadal zachowano tytuły profesora zwyczajnego i nadzwyczajnego, lecz po raz pierwszy nazwano je wprost tytułami naukowymi. Ich przyznawanie powierzono, także po raz pierwszy, nowo utworzonej Centralnej Komisji Kwalifikacyjnej do Spraw Pracowników Naukowych, podległej prezesowi Rady Ministrów.

Ustawa z 1958 r. tego komunistycznego wpływu wiele nie zmieniła, choć przyjęte nią rozwiązania znacznie odbiegały od rozwiązań lat wcześniejszych. Powrócono do nadawania tytułów naukowych profesora zwyczajnego i nadzwyczajnego.

Na przestrzeni lat objętych oceną zmianom podlegały: organy przyznające tytuły profesora (Naczelnik Państwa, Prezydent Rzeczypospolitej, Centralna Komisja do Spraw Pracowników Nauki, Rada Państwa, Prezydent Rzeczypospolitej), podmioty współuczestniczące w procesie przyznawania (w drodze nadania tytułu lub mianowania) profesora nadzwyczajnego i zwyczajnego (właściwy minister, zebranie ogólne profesorów, senat, rada wydziału lub rada naukowa, rektor, sekretarz PAN, Rada Główna Szkolnictwa Wyższego), wymagania stawiane przed kandydatami do tytułu profesora - naukowe (dorobek naukowy powiększony, wydatnie powiększony bądź poważny dorobek naukowy) i moralne.

Wszystko to dowodzi niezmiernie dużej ingerencji politycznych założeń w proces kształtowania nie tylko polityki naukowej i wyznaczania granic wolności badań naukowych, ale także wymagań stawianych 
przed osobami kandydującymi do tytułów profesorskich, poprzez zmienną w czasie politykę dotyczącą kształtowania tychże wymagań oraz postaw i aspiracji naukowych pracowników nauki, nierzadko dalekich od swobody wyboru tematów badawczych i wolności (kreatywności) ich ujmowania.

\section{THE TITLE OF PROFESSOR IN POLAND IN THE YEARS 1920-1990. PART 1. CONDITIONS FOR THE AWARD OF THE TITLE OF PROFESSOR UNDER THE LAW ON SCHOOLS OF HIGHER EDUCATION}

\section{Su m mary}

The Polish law on schools of higher education of the past years did not provide a uniformed definition of the institution of the title of professor. Differences in its treatment generally corresponded to the legal and factual conditions in which the institutions of higher education were operating in interwar Poland in the first years of the Polish People's Republic. This was not a period of simple change. The first establishments of higher education operating after 1918, and also after the end of World War II, were struggling not only with the acquisition of professors. Later years, despite the opening of new schools of higher education, did not manage to solve the problem of professorship shortages. What was more, a new threat emerged that was ideologisation of universities and scientific research. Gradually ideological assumptions had become the criteria of professorship selection. This state of affairs changed only as a result of the political transformation after 1989.

In the interwar Poland and the first years of the Polish People's Republic, the law provided for two titles of professor: extraordinary and ordinary. A special position was also given to honorary professors, and the award of other professorships was not an isolated act. The shortage of professorship staff was compensated by awarding titles of titular professor, contract professor and deputy professor. This solution continued to prevail in the early years of the Polish People's Republic and changed only in 1952 when the Act of 1951 came into force. It provided for two scientific titles: the extraordinary professor and the ordinary professor. The Act of 1958 Act extended their number by including the titles of contract professor and deputy professor and specified other conditions for awarding these titles.

The article presents legal solutions of the past years not only in the scope in which they served the selection of professors' staff and the conditions of scientific advancement set for them in particular years, as well as the conditions in which these advancements were possible.

Keywords: award of the scientific title of professor - appointment to the position of professor - framework for the freedom of scientific research 